\title{
A Comprehensive Overview on the Production of Vaccines in Plant-Based Expression Systems and the Scope of Plant Biotechnology to Combat against SARS-CoV-2 Virus Pandemics
}

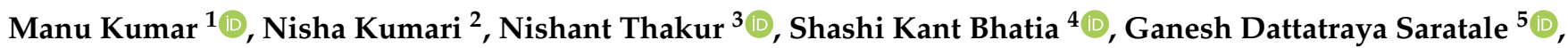

 \\ and Sang-Min Chung ${ }^{1, *}$
}

Citation: Kumar, M.; Kumari, N.; Thakur, N.; Bhatia, S.K.; Saratale, G.D.; Ghodake, G.; Mistry, B.M.; Alavilli, H.; Kishor, D.S.; Du, X.; et al. A Comprehensive Overview on the Production of Vaccines in Plant-Based Expression Systems and the Scope of Plant Biotechnology to Combat against SARS-CoV-2 Virus Pandemics. Plants 2021, 10, 1213. https:// doi.org/10.3390/plants10061213

Academic Editor: Tomasz Pniewski

Received: 19 April 2021

Accepted: 12 June 2021

Published: 15 June 2021

Publisher's Note: MDPI stays neutral with regard to jurisdictional claims in published maps and institutional affiliations.

Copyright: (c) 2021 by the authors. Licensee MDPI, Basel, Switzerland. This article is an open access article distributed under the terms and conditions of the Creative Commons Attribution (CC BY) license (https:// creativecommons.org/licenses/by/ $4.0 /)$.
1 Department of Life Science, College of Life Science and Biotechnology, Dongguk University, Seoul 10326, Korea; manukumar007@gmail.com (M.K.); kishoreflmes@gmail.com (D.S.K.); duxueshii@gmail.com (X.D.)

2 Department of Radiology, Seoul National University Hospital, Seoul National University College of Medicine, Seoul 03080, Korea; nishak.chambyal88@gmail.com

3 Department of Hospital Pathology, Yeouido St. Mary's Hospital, College of Medicine, The Catholic University of Korea, 10, 63-ro, Yeongdeungpo-gu, Seoul 07345, Korea; nishantbiotech2014@gmail.com

4 Department of Biological Engineering, College of Engineering, Konkuk University, 1 Hwayang-dong, Gwangjin-gu, Seoul 05029, Korea; shashibiotechhpu@gmail.com

5 Department of Food Science and Biotechnology, Dongguk University, Seoul 10326, Korea; gdsaratale@gmail.com (G.D.S.); bhupendra.mistry84@gmail.com (B.M.M.)

6 Department of Biological and Environmental Science, Dongguk University, Seoul 10326, Korea; ghodakegs@gmail.com

7 Department of Biochemistry and Molecular Biology, College of Medicine, Korea University, Seoul 02841, Korea; alavilli.sundar@gmail.com

* Correspondence: smchung@dongguk.edu

Abstract: Many pathogenic viral pandemics have caused threats to global health; the COVID-19 pandemic is the latest. Its transmission is growing exponentially all around the globe, putting constraints on the health system worldwide. A novel coronavirus, severe acute respiratory syndrome coronavirus-2 (SARS-CoV-2), causes this pandemic. Many candidate vaccines are available at this time for COVID-19, and there is a massive international race underway to procure as many vaccines as possible for each country. However, due to heavy global demand, there are strains in global vaccine production. The use of a plant biotechnology-based expression system for vaccine production also represents one part of this international effort, which is to develop plant-based heterologous expression systems, virus-like particles (VLPs)-vaccines, antiviral drugs, and a rapid supply of antigen-antibodies for detecting kits and plant origin bioactive compounds that boost the immunity and provide tolerance to fight against the virus infection. This review will look at the plant biotechnology platform that can provide the best fight against this global pandemic.

Keywords: SARS-CoV-2 virus; COVID-19 vaccine; bio-farming; respiratory disorder; vaccine

\section{Introduction}

In late 2019, a potentially lethal outbreak of novel coronavirus (SARS-Cov-2) with the fatal respiratory syndrome was reported in Wuhan, China [1]. This outbreak has created a pandemic all over the world. Up to June 2021 (sixteen months after its emergence), it has caused more than 175,306,598 cases of infections and more than 3,792,777 deaths worldwide, affecting 223 countries (WHO) [2]. COVID-19 has a higher mortality rate $(\sim 2.2 \%)$ and transmissibility than the influenza A virus subtype H1N1 pandemic, which has a mortality rate of around $0.02 \%$. Coronaviruses are single-stranded RNA virus that is grouped into four categories: $\alpha$-CoVs, $\beta$-CoVs, $\gamma$-CoVs, and $\delta$-CoVs. 
Governments are trying to control this outbreak by emergency containment and rapid testing. These measures will slow the infection rate, reduce the mortality rate, and prevent the healthcare system from collapsing. In addition, it will allow researchers to have enough time to develop fast testing kits and treatments that limit the infection and the candidate vaccine to immunize the population. Researchers working on plant-based vaccines can also play a crucial role during this crucial time by using their knowledge and platform to develop a reagent as early as possible compared to months and years based on a cell-based platform.

\section{Progress in Prophylactic and Therapeutic Treatments against COVID-19}

\subsection{Candidate Vaccine for COVID-19}

For COVID-19, there is no specific treatment at this stage. Several technological gaps exist for SARS-CoV-2 virus understanding, as it is still an early stage for this pathogen. Currently, 102 candidate vaccines are in clinical trials, and 185 candidate vaccines are in preclinical trials [3]. Thirty-one percent of candidate vaccines are based on protein subunit platforms (Table 1). WHO issued an emergency use listing (EULs) for the mRNAbased Pfizer COVID-19 vaccine (BNT162b2) on 31 December 2020. On 15 February 2021, WHO again issued EULs for two versions of the viral vector-based AstraZeneca/Oxford COVID-19 vaccine, manufactured by the Serum Institute of India and SKBio [3]. There are more than 15 other candidate vaccines that await WHO listing. An international effort is ongoing for vaccine procurements. Simultaneously, the determination of the efficacy of preexisting antiviral drugs, such as Remdesivir, Nafamostat, and camostat, is taking place [4-6]. Receptors are essential for the attachment of any virus, and by blocking the receptor, virus attachment can be inhibited. It is reported that losartan (an angiotensin receptor 1 blockers) might have tentative SARS-CoV-2 therapeutics value since angiotensinconverting enzyme 2 (ACE2) likely to serves as the binding site for the SARS-CoV-2 [7,8]. Transfusing plasma from individuals recovered from COVID-19 infection also shows promise as plasma contains neutralizing antibodies for SARS-CoV-2 [9]. For the control and timely eradication of infectious diseases, vaccination is the most potent weapon. Since transmission of SARS-CoV-2 is very high, there is an urgency to develop the vaccine and eradicate this virus. The simplest way to generate a candidate vaccine lies in the technology where an inactivated virus can be used for vaccine production [10]. The live-attenuated virus vaccine is another possible approach where these vaccines lost their pathogenic properties and caused only a mild infection upon injection [11].

Table 1. The COVID-19 candidate vaccine in clinical trials.

\begin{tabular}{cccc}
\hline & Platform & \multicolumn{2}{c}{ Candidate Vaccines } \\
\hline $\mathbf{1}$ & Protein subunit & Number & Percentage \\
\hline $\mathbf{2}$ & Viral Vector (non-replicating) $(\mathrm{VVnr})$ & 16 & Thirty-one \\
\hline $\mathbf{3}$ & DNA & 10 & Sixteen \\
\hline $\mathbf{4}$ & Inactivated Virus (IV) & 16 & Ten \\
\hline $\mathbf{5}$ & RNA & 16 & Sixteen \\
\hline $\mathbf{6}$ & Viral Vector (replicating) $(\mathrm{VVr})$ & 2 & Two \\
\hline $\mathbf{7}$ & Virus-Like Particle (VLP) & 5 & Five \\
\hline $\mathbf{8}$ & VVr + Antigen Presenting Cell (VVr+APC) & 2 & Two \\
\hline $\mathbf{9}$ & Live Attenuated Virus (LAV) & 2 & Two \\
\hline $\mathbf{1 0}$ & VVnr + Antigen Presenting Cell (VVnr+APC) & 1 & One \\
\hline Total & & 102 & \\
\hline
\end{tabular}


An earlier candidate inactivated virus vaccine for MERS-CoV and SARS-CoV-1 has helped neutralize the virus [12-14]. Another path is to construct a recombinant live attenuated vaccine virus that can protect from SARS-CoV-2 and respiratory syncytial virus. It has already been reported in the case of the influenza virus vaccine [15]. Another alternate can be an adenovirus-based vaccine that prevented pneumonia from SARS coronavirus and stimulated a good immune response in macaques [13]. Adenoviruses are vectors used to deliver vaccine antigens to the target host tissues and are being tested in several gene therapies and vaccine studies [16]. Several leading adenovirus-based vaccine candidates are in advanced phases of clinical trials (Table 2), such as ChAdOx1-S-(AZD1222) (Covishield) (AstraZeneca + University of Oxford), Recombinant novel coronavirus vaccine (Adenovirus type 5 vector) (CanSino Biological Inc./Beijing Institute of Biotechnology), Gam-COVIDVac Adeno-based (rAd26-S + rAd5-S) (Gamaleya Research Institute; Health Ministry of the Russian Federation), Ad26.COV2.S (Janssen Pharmaceutical). Another approach would be a DNA-based vaccine, where deoxyribose nucleic acid (DNA) codes for specific proteins (antigens) from a pathogen are injected into the body and taken up by cells and generate an immune response. The nCov vaccine from Zydus Cadila is a DNA-based vaccine in the advanced clinical trials phase. Even though many countries are rushing towards generating vaccines for SARS-CoV-2, safety regulation guarantees should not be ignored [17]. Most of the candidate vaccines in advanced clinical trials have good efficacy data (Table 2).

Along with the inactivated vaccines approach, an alternative method should be explored for candidate vaccines. Since spike protein trimers are the primary binding sites of the ACE2 receptor of a host cell, it makes this protein an easy target for antibody neutralization (Figure 1) [18,19].

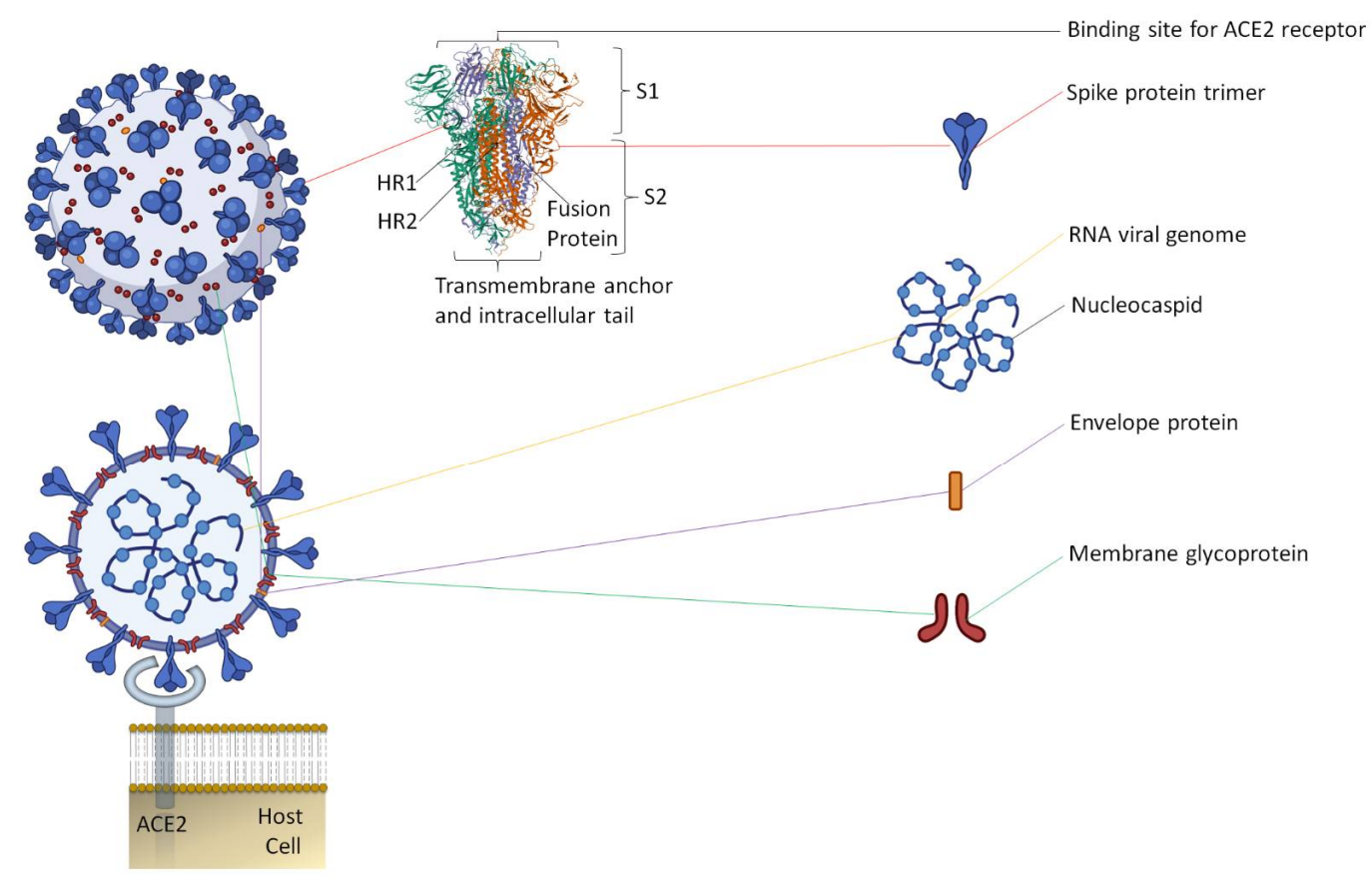

Figure 1. The representative two-dimensional structure of Severe Acute Respiratory Syndrome Coronavirus 2 (SARS-CoV-2) shows the trimeric spike protein's prominent position. The virus is constituted by an envelope membrane that is associated with the structural proteins, such as spike protein trimer, which mediates binding to the host cell ACE2 receptors and considered a vital target for the activation of a primary defense mechanism by the induction of antibodies that are capable of neutralizing the virus. 2-D structure (PDB ID: 6XLU) of spike protein has two subunits, S1 and S2. S2 subunit has two main domain, HR1 (912-984 aa) and HR2 (1163-1213 aa), along with fusion protein that contains the significant parts of HR1 (residues 910-988) and HR2 (residues 1162-1206); a membrane glycoprotein, which is essential to generate the virus; and the envelope protein, which adheres to the membrane glycoprotein to form the viral envelope. The viral structure also comprises a nucleocaspid protein that, along with the RNA genome, produces the nucleocaspid. The figure includes some images from Biorender (https:/ / biorender.com/, accessed on 12 June 2021). 
Table 2. WHO list of candidate vaccines for COVID-19 in advanced trials [3].

\begin{tabular}{|c|c|c|c|c|c|c|c|c|c|}
\hline Sr. No. & Vaccine Platform & $\begin{array}{c}\text { Type of Candidate } \\
\text { Vaccine }\end{array}$ & No. of Doses & Adjuvant & Schedule & $\begin{array}{c}\text { Route of } \\
\text { Administration }\end{array}$ & Developers & Phase & $\begin{array}{l}\text { Clinical Trials } \\
\text { (gov.Identifier) }\end{array}$ \\
\hline 1 & $\begin{array}{l}\text { Inactivated virus } \\
\text { (IV) }\end{array}$ & $\begin{array}{c}\text { CoronaVac; } \\
\text { SARS-CoV-2 } \\
\text { vaccine } \\
\text { (inactivated) }\end{array}$ & 2 & $\begin{array}{l}\text { Aluminium } \\
\text { hydroxide gel } \\
\text { (Algel) }\end{array}$ & Day $0+14$ & $\mathrm{IM}$ & $\begin{array}{l}\text { Sinovac Research } \\
\text { and Development } \\
\text { Co., Ltd. }\end{array}$ & Phase 4 & NCT04775069 \\
\hline 2 & $\begin{array}{l}\text { Inactivated virus } \\
\text { (IV) }\end{array}$ & $\begin{array}{c}\text { Inactivated } \\
\text { SARS-CoV-2 } \\
\text { vaccine (Vero cell) }\end{array}$ & 2 & $\begin{array}{l}\text { Aluminium } \\
\text { hydroxide gel } \\
\text { (Algel) }\end{array}$ & Day $0+21$ & $\mathrm{IM}$ & $\begin{array}{l}\text { Sinopharm + China } \\
\text { National Biotec } \\
\text { Group Co + Wuhan } \\
\text { Institute of } \\
\text { Biological Products }\end{array}$ & Phase 3 & NCT04612972 \\
\hline 3 & $\begin{array}{l}\text { Inactivated virus } \\
\text { (IV) }\end{array}$ & $\begin{array}{c}\text { BBIBP-CorV, } \\
\text { Inactivated } \\
\text { SARS-CoV-2 } \\
\text { vaccine (Vero cell) }\end{array}$ & 2 & $\begin{array}{l}\text { Aluminium } \\
\text { hydroxide gel } \\
\text { (Algel) }\end{array}$ & Day $0+21$ & $\mathrm{IM}$ & $\begin{array}{l}\text { Sinopharm + China } \\
\text { National Biotec } \\
\text { Group Co + Beijing } \\
\text { Institute of } \\
\text { Biological Products }\end{array}$ & Phase 3 & NCT04510207* \\
\hline 4 & $\begin{array}{c}\text { Whole-Virion } \\
\text { Inactivated } \\
\text { SARS-CoV-2 } \\
\text { Vaccine (BBV152) }\end{array}$ & $\begin{array}{l}\text { Inactivated virus } \\
\text { vaccine }\end{array}$ & 2 & $\begin{array}{l}\text { Aluminium } \\
\text { hydroxide gel } \\
\text { (Algel) }\end{array}$ & Day $0+14$ & $\mathrm{IM}$ & $\begin{array}{l}\text { Bharat Biotech } \\
\text { International } \\
\text { Limited }\end{array}$ & Phase 3 & $\begin{array}{c}\text { NCT04641481; } \\
\text { CTRI/2020/11/028976 }\end{array}$ \\
\hline 5 & $\begin{array}{l}\text { SARS-CoV-2 } \\
\text { vaccine (vero } \\
\text { cells) }\end{array}$ & $\begin{array}{l}\text { Inactivated virus } \\
\text { vaccine }\end{array}$ & 2 & $\begin{array}{l}\text { Aluminium } \\
\text { hydroxide gel } \\
\text { (Algel) }\end{array}$ & Day $0+28$ & $\mathrm{IM}$ & $\begin{array}{c}\text { Institute of Medical } \\
\text { Biology + Chinese } \\
\text { Academy of } \\
\text { Medical Sciences }\end{array}$ & Phase 3 & NCT04659239 \\
\hline 6 & $\begin{array}{c}\text { QazCovid-in }{ }^{\circledR} \\
\text {-COVID-19 } \\
\text { (Inactivated virus) }\end{array}$ & $\begin{array}{l}\text { Inactivated virus } \\
\text { vaccine }\end{array}$ & 2 & No & Day $0+21$ & $\mathrm{IM}$ & $\begin{array}{l}\text { Research Institute } \\
\text { for Biological Safety } \\
\text { Problems, Rep of } \\
\text { Kazakhstan }\end{array}$ & Phase 3 & NCT04691908 \\
\hline 7 & $\begin{array}{c}\text { Viral vector } \\
\text { (Non-replicating) } \\
\text { (VVnr) }\end{array}$ & $\begin{array}{l}\text { ChAdOx1-S- } \\
\text { (AZD1222) } \\
\text { (Covishield, } \\
\text { Vaxzevria) }\end{array}$ & $1-2$ & No & Day $0+28$ & $\mathrm{IM}$ & $\begin{array}{l}\text { AstraZeneca + } \\
\text { University of } \\
\text { Oxford }\end{array}$ & Phase 4 & NCT04775069 \\
\hline
\end{tabular}


Table 2. Cont.

\begin{tabular}{|c|c|c|c|c|c|c|c|c|c|}
\hline Sr. No. & Vaccine Platform & $\begin{array}{c}\text { Type of Candidate } \\
\text { Vaccine }\end{array}$ & No. of Doses & Adjuvant & Schedule & $\begin{array}{c}\text { Route of } \\
\text { Administration }\end{array}$ & Developers & Phase & $\begin{array}{r}\text { Clinical Trials } \\
\text { (gov.Identifier) }\end{array}$ \\
\hline 8 & $\begin{array}{c}\text { Viral vector } \\
\text { (Non-replicating) } \\
\text { (VVnr) }\end{array}$ & $\begin{array}{c}\text { Recombinant novel } \\
\text { coronavirus vaccine } \\
\text { (Adenovirus type } 5 \\
\text { vector) }\end{array}$ & 1 & No & Day 0 & $\mathrm{IM}$ & $\begin{array}{l}\text { CanSino Biological } \\
\text { Inc./Beijing } \\
\text { Institute of } \\
\text { Biotechnology }\end{array}$ & Phase 4 & NCT04540419 \\
\hline 9 & $\begin{array}{c}\text { Viral vector } \\
\text { (Non-replicating) } \\
\text { (VVnr) }\end{array}$ & $\begin{array}{c}\text { Gam-COVID-Vac } \\
\text { Adeno-based } \\
\text { (rAd26-S+rAd5-S) }\end{array}$ & 2 & No & Day $0+21$ & $\mathrm{IM}$ & $\begin{array}{l}\text { Gamaleya Research } \\
\text { Institute; Health } \\
\text { Ministry of the } \\
\text { Russian Federation }\end{array}$ & Phase 3 & NCT04741061 \\
\hline 10 & $\begin{array}{c}\text { Viral vector } \\
\text { (Non-replicating) } \\
\text { (VVnr) }\end{array}$ & Ad26.COV2.S & $1-2$ & $\begin{array}{l}\text { aluminum } \\
\text { phosphate } \\
\text { adjuvant } \\
\text { (Adjuphos) }\end{array}$ & $\begin{array}{c}\text { Day } 0 \text { or Day } 0 \\
+56\end{array}$ & $\mathrm{IM}$ & $\begin{array}{c}\text { Janssen } \\
\text { Pharmaceutical }\end{array}$ & Phase 3 & NCT04614948 \\
\hline 11 & Protein subunit & $\begin{array}{c}\text { SARS-CoV-2 } \\
\text { rS/Matrix } \\
\text { M1-Adjuvant (Full } \\
\text { length recombinant } \\
\text { SARS CoV-2 } \\
\text { glycoprotein } \\
\text { nanoparticle } \\
\text { vaccine adjuvanted } \\
\text { with Matrix M) }\end{array}$ & 2 & Matrix-M ${ }^{\mathrm{TM}}$ & Day $0+21$ & $\mathrm{IM}$ & Novavax & Phase 3 & NCT04583995 \\
\hline 12 & Protein subunit & $\begin{array}{c}\text { Recombinant } \\
\text { SARS-CoV-2 } \\
\text { vaccine (CHO Cell) }\end{array}$ & $2-3$ & $\begin{array}{l}\text { Aluminium } \\
\text { hydroxide gel } \\
\text { (Algel) }\end{array}$ & $\begin{array}{c}\text { Day } 0+28 \text { or } \\
\text { Day } 0+28+ \\
56\end{array}$ & $\mathrm{IM}$ & $\begin{array}{c}\text { Anhui Zhifei } \\
\text { Longcom } \\
\text { Biopharmaceutical + } \\
\text { Institute of } \\
\text { Microbiology, } \\
\text { Chinese Academy } \\
\text { of Sciences }\end{array}$ & Phase 3 & NCT04646590 \\
\hline
\end{tabular}


Table 2. Cont.

\begin{tabular}{|c|c|c|c|c|c|c|c|c|c|}
\hline Sr. No. & Vaccine Platform & $\begin{array}{c}\text { Type of Candidate } \\
\text { Vaccine }\end{array}$ & No. of Doses & Adjuvant & Schedule & $\begin{array}{c}\text { Route of } \\
\text { Administration }\end{array}$ & Developers & Phase & $\begin{array}{l}\text { Clinical Trials } \\
\text { (gov.Identifier) }\end{array}$ \\
\hline 13 & Protein subunit & $\begin{array}{c}\text { VAT00002: } \\
\text { SARS-CoV-2 } \\
\text { vaccine formulation } \\
1 \text { with adjuvant } 1 \text { ( } \mathrm{S} \\
\text { protein (baculovirus } \\
\text { production) }\end{array}$ & 2 & AS03 & Day $0+21$ & $\mathrm{IM}$ & $\begin{array}{c}\text { Sanofi Pasteur + } \\
\text { GSK }\end{array}$ & Phase 3 & PACTR202011523101903 ** \\
\hline 14 & $\begin{array}{l}\text { Protein subunit } \\
\text { (SOBERANA 02) }\end{array}$ & $\begin{array}{l}\text { FINLAY-FR-2 } \\
\text { anti-SARS-CoV-2 } \\
\text { Vaccine (RBD } \\
\text { chemically } \\
\text { conjugated to } \\
\text { tetanus toxoid plus } \\
\text { adjuvant) }\end{array}$ & 2 & $\begin{array}{l}\text { Aluminium } \\
\text { hydroxide gel } \\
\text { (Algel) }\end{array}$ & Day $0+28$ & $\mathrm{IM}$ & $\begin{array}{l}\text { Instituto Finlay de } \\
\text { Vacunas }\end{array}$ & Phase 3 & RPCEC00000354 \\
\hline 15 & Protein subunit & $\begin{array}{l}\text { EpiVacCorona } \\
\text { (EpiVacCorona } \\
\text { vaccine based on } \\
\text { peptide antigens for } \\
\text { the prevention of } \\
\text { COVID-19) }\end{array}$ & 2 & $\begin{array}{l}\text { Aluminium } \\
\text { hydroxide gel } \\
\text { (Algel) }\end{array}$ & Day $0+21$ & $\mathrm{IM}$ & $\begin{array}{c}\text { Federal Budgetary } \\
\text { Research Institution } \\
\text { State Research } \\
\text { Center of Virology } \\
\text { and Biotechnology } \\
\text { "Vector" }\end{array}$ & Phase 3 & NCT04780035 \\
\hline 16 & $\begin{array}{l}\text { RNA based } \\
\text { vaccine }\end{array}$ & mRNA -1273 & 2 & No & Day $0+28$ & $\mathrm{IM}$ & $\begin{array}{l}\text { Moderna + National } \\
\text { Institute of Allergy } \\
\text { and Infectious } \\
\text { Diseases (NIAID) }\end{array}$ & Phase 4 & NCT04760132 \\
\hline 17 & $\begin{array}{l}\text { RNA based } \\
\text { vaccine }\end{array}$ & $\begin{array}{l}\text { BNT162 (3 } \\
\text { LNP-mRNAs), } \\
\text { Comirnaty }\end{array}$ & 2 & No & Day $0+21$ & $\mathrm{IM}$ & $\begin{array}{c}\text { Pfizer/BioNTech + } \\
\text { Fosun Pharma }\end{array}$ & Phase 4 & NCT04775069 \\
\hline 18 & $\begin{array}{l}\text { RNA based } \\
\text { vaccine }\end{array}$ & CVnCoV Vaccine & 2 & CV8102 & Day $0+28$ & $\mathrm{IM}$ & CureVac AG & Phase 3 & NCT04674189 \\
\hline 19 & $\begin{array}{l}\text { DNA based } \\
\text { vaccine } \\
(\mathrm{ZyCoV}-\mathrm{D})\end{array}$ & nCov vaccine & 3 & No & $\begin{array}{c}\text { Day } 0+28+ \\
56\end{array}$ & ID & Zydus Cadila & Phase 3 & CTRI/2020/07/026352 \\
\hline
\end{tabular}

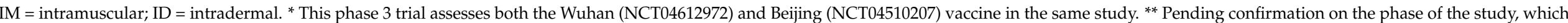

is not specified in the registry. 
Another approach would be RNA-based vaccines. Here, instead of the standard vaccines where viral proteins are used to immunize, the messenger RNA vaccine will provide a synthetic mRNA of the virus, which the host body will use to produce an immune response [20-26]. The most significant advantage of the RNA vaccines is that they are translated in the cytosol, so there is no need for the RNA to enter the cell nucleus, and the risk of being integrated into the host genome is averted [27]. RNA-based candidate vaccine that are in most advanced phased of clinical trials are mRNA-1273 (Moderna + National Institute of Allergy and Infectious Diseases), BNT162b2 (Pfizer/BioNTech + Fosun Pharma), CVnCoV (CureVac AG) [28,29] (Table 2). An inactivated virus vaccine is also another approach, where a killed version of the virus is used. Inactivated vaccines usually cannot provide immunity as much as live vaccines. Several booster doses over a while are required to get uninterrupted immunity against particular diseases. Several vaccine candidates used Inactivated virus such as CoronaVac (Sinovac Research), Inactivated SARS-CoV-2 vaccine (Sinopharm + China National Biotec Group Co + Wuhan Institute of Biological Products), Sinopharm + China National Biotec Group Co + Beijing Institute of Biological Products, Institute of Medical Biology + Chinese Academy of Medical Sciences, QazCovid-in ${ }^{\circledR}$ (Research Institute for Biological Safety Problems, Rep of Kazakhstan), BBV152 (Bharat Biotech International Limited). There are other candidate vaccines also that used protein subunit of SARS-CoV-2. Protein-based subunit vaccine presents an antigen to the immune system without viral particles using a specific pathogen protein (Table 2). These candidate vaccines have shown well-documented immunogenicity in the preliminary studies [30]. Using bioinformatics for the detailed analysis of sequence analysis is another approach to predict immune response for SARS-CoV-2 [31]. SARSCoV-2 structure's analysis will help in understanding the response strategy towards this virus. There are reports about the structure, function, and antigenicity predictions of the SARS-CoV-2 spike glycoprotein [19]. These predictions will be important for the designing of vaccines and inhibitors of viral receptors. Another study reports that the crystal structure of SARS-CoV-2 main protease provides a basis for the design of improved $\alpha$-ketoamide inhibitors [32]. These recent studies will help in the ongoing effort to produce effective vaccines, but in parallel to this vaccine development, a reliable alternative platform that can provide rapid and large-scale vaccine production is needed. The platform must be designed to keep in mind low cost, easy distribution, and special campaigns in poor and developing countries.

\subsection{Promising Adjuvants Used for the Development of COVID-19 Vaccines}

Adjuvants are critical components of some inactivated and subunit vaccines because they help in boosting the specific immune responses against vaccine antigens $[33,34]$. In the last decades, many materials have been tried and tested as adjuvants. Examples include bacterial metabolites [35,36], mineral oil/surfactant with immune-stimulant [37], microparticles [38,39], nucleic acids [40], liposomes [41,42], and polysaccharide [43]. However, only aluminum-based adjuvants continue to be used worldwide [44].

Alum (aluminum hydroxide) is one of the most commonly used adjuvants. Its mechanism of action is complex. So far, multiple hypotheses have come to light to explain its mode of action [45]. It forms a depot at the injection site allowing a slow release of antigen; it prolongs the interaction time between antigen-presenting cells (APCs) and antigen; further, it converts soluble antigens into readily phagocytosed particulate forms [46]. Aluminum hydroxide directly stimulates monocytes at the cellular level to produce pro-inflammatory cytokines activating T cells. Most of the COVID-19 vaccines are using aluminum hydroxide as their adjuvant (Table 2).

Another aluminum adjuvant commonly used in vaccine productions is aluminum phosphate (AlPO4). It also stimulates the immune response against antigens. They are required for the efficacy and optimal immunogenicity of many vaccines. Onto the surface of adjuvants, different antigens adsorb to different extents and can undergo structural changes that may destabilize or stabilize the antigens. Upon adjuvant action, bovine serum 
albumin, lysozyme, and ovalbumin experience a decrease in the unfolding temperature [47]. In another study, antigen protein for tuberculosis vaccine candidates became more stable upon adsorption onto a different type of adjuvant [48]. Janssen Pharmaceutical using AlPO4 as an adjuvant for their COVID-19 vaccine Ad26.COV2.S (Table 2).

Another adjuvant CV8102 is a TLR 7/8 agonist and RIG I pathway activator to enhance the immunogenicity of poorly immunogenic antigens. It is an RNA-based adjuvant (RNAdjuvant ${ }^{\circledR}$, CureVac AG) [49,50]. It consists of uncapped, non-coding, PolyU repeats-containing single-stranded RNA with a 5-triphosphate modification complexed with a polymeric carrier and a small arginine-rich disulfide-cross-linked cationic peptide (CR12C) [50,51]. CureVac AG RNA based vaccine CVnCoV using CV8102 as an adjuvant.

Another important adjuvant, AS03, has a polysorbate 80, surfactant, two biodegradable oils, squalene, and $\alpha$-tocopherol in phosphate-buffered saline as the aqueous carrier [52]. These adjuvant capabilities derive from the $\alpha$-tocopherol, and oil-in-water emulsion phase, for which immunostimulatory properties have been described [53]. After a cascade of reactions, the ASO3 adjuvant enhances adaptive immune responses to the vaccine antigen $[52,54]$. The Sanofi Pasteur protein subunit vaccine VAT00002 uses the GSK adjuvant AS03.

The Novavax protein subunit vaccine uses Matrix-M as an adjuvant (Table 2). It is made of Quillaja saponins formulated with phospholipids and cholesterol into nanoparticles and is known to augment Th1 and Th2, inducing antibodies of multiple subclasses that enhance immune cell trafficking and allow antigen dose-sparing [55-60].

\section{Plant Biotechnology-Based Vaccines and Bio-Farming?}

Transgenic plant from a genetic engineering approach provides a perfect platform for the manufacturing of large-scale biopharmaceuticals. In the last three decades, these plants have been used widely for the production of biopharmaceuticals. This approach has produced a wide range of biopharmaceuticals, such as cytokines, growth factors, antibodies, and vaccines [61].

The production of antibodies in transgenic tobacco plants was reported by Hiatt et al. [62]. It was the first example of bio-farming, where the aim is to recover and use only protein products instead of the whole plant [63-65]. Recombinant human serum albumin is produced in transgenic potato and tobacco plants by overexpressing the human serum albumin gene [66,67]. These path-breaking studies open the flood gates for bio-farming in plants [68]. These plant-based viral expression systems' main advantages are to avoid human pathogens replication, easy synthesis of complex proteins, and utilization of simple bioreactors $[69,70]$.

\subsection{Strategies for the Production of Recombinant Proteins in Plant-Based Expression Systems}

In plant-based expression systems, there are three main approaches for recombinant protein production [28]: (1) by developing transgenic plants carrying stably integrated transgenes [63]; (2) using cell-culture-based systems equivalent to microbial, insect cell, and mammalian systems; and (3) by transient expression of foreign genes in plant tissues transformed by either a viral infection or agroinfection [66,71,72]. For a foreign gene's proper function in a host cell, the gene must replicate into many copies in the cell's nucleus; hence, these transient expressions happen at the nucleus. Currently, transiently transformed plants at nuclear or chloroplast are used to produce expressed recombinant protein. In Table 3, the expression method is summarized. 
Table 3. Summary of the different expression approaches for producing plant-based vaccines and their function as MERS/SARS-CoV-1 vaccines.

\begin{tabular}{|c|c|c|c|c|c|c|c|c|c|}
\hline Method & Features & Limitations & $\begin{array}{l}\text { Target/Plant } \\
\text { Species }\end{array}$ & $\begin{array}{l}\text { The Protein } \\
\text { Used/Route of } \\
\text { Inoculation }\end{array}$ & $\begin{array}{l}\text { Experimental } \\
\text { Phase }\end{array}$ & Dose & $\begin{array}{l}\text { Degree and Type } \\
\text { of Protection } \\
\text { Generated }\end{array}$ & Functions & Reference \\
\hline $\begin{array}{l}\text { Stable nuclear } \\
\text { transformation }\end{array}$ & $\begin{array}{l}\text { Seed bank } \\
\text { possible; } \\
\text { Inheritable } \\
\text { antigen } \\
\text { production; Many } \\
\text { methods are } \\
\text { available for } \\
\text { different crops }\end{array}$ & $\begin{array}{l}\text { Random insertion; } \\
\text { Possibility of } \\
\text { horizontal gene } \\
\text { transfer; position } \\
\text { effects and } \\
\text { gene silencing; } \\
\text { transformation is } \\
\text { tedious }\end{array}$ & $\begin{array}{l}\text { Full and truncated } \\
\mathrm{S} \text { protein/tomato } \\
\text { and tobacco }\end{array}$ & $\begin{array}{l}\text { Purified Protein/In } \\
\text { saline and oral } \\
\text { immunization }\end{array}$ & Pre-clinical & $\begin{array}{c}500 \mathrm{mg} \text { of dry } \\
\text { tomato fruit, } \\
50 \mathrm{mg} \text { of dry } \\
\text { tobacco root, } \\
\text { 2-week intervals, } \\
\text { after a } 4 \text {-week } \\
\text { booster dose of } \\
1 \mu \mathrm{g} \text { of } \\
\text { commercially } \\
\text { obtained S peptide } \\
\text { without adjuvant. }\end{array}$ & $\begin{array}{l}\text { Significantly } \\
\text { increased levels of } \\
\text { SARS-CoV- } \\
\text { specific IgA after } \\
\text { oral ingestion of } \\
\text { tomato fruits } \\
\text { expressing S1 } \\
\text { protein. }\end{array}$ & $\begin{array}{l}\text { Expression of SARS-CoV } \\
\text { S protein (S1) in tomato } \\
\text { and tobacco plants and } \\
\text { after oral ingestion of } \\
\text { tomato fruits, mice } \\
\text { display elevated } \\
\text { SARS-CoV-specific } \\
\text { IgA levels. }\end{array}$ & [73] \\
\hline $\begin{array}{l}\text { Transient nuclear } \\
\text { transformation }\end{array}$ & $\begin{array}{l}\text { High and rapid } \\
\text { protein } \\
\text { production; } \\
\text { Industrial } \\
\text { scale production }\end{array}$ & $\begin{array}{l}\text { The seed bank is } \\
\text { impossible; } \\
\text { requires } \\
\text { purification of } \\
\text { the antigen; }\end{array}$ & $\begin{array}{l}\text { Partial spike } \\
\text { protein of } \\
\text { SARS-CoV; } \\
\text { recombinant } \\
\text { nucleocapsid } \\
\text { (rN)and the } \\
\text { membrane protein } \\
(\mathrm{M}) / \text { tobacco }\end{array}$ & $\begin{array}{l}\text { Purified Pro- } \\
\text { tein/Intraperitoneally }\end{array}$ & Pre-clinical & $2-4 \mu \mathrm{g} \mathrm{rN}$ protein & $\begin{array}{l}\text { Vaccination of } \\
\text { BALB/c mice with } \\
\text { tobacco-expressed } \\
\text { rN protein } \\
\text { successfully led to } \\
\text { a specific B-cell } \\
\text { response. }\end{array}$ & $\begin{array}{l}\text { Produced S1 proteins in } \\
\text { chloroplast- and } \\
\text { nuclear-transformed } \\
\text { plants display potential } \\
\text { in safe oral recombinant } \\
\text { subunit vaccine. The } \\
\text { expression of IL-10 and } \\
\text { IFN- } \gamma \text { was up-regulated } \\
\text { during the vaccination } \\
\text { of rN protein, while IL-4 } \\
\text { and IL-2 expression } \\
\text { were not. }\end{array}$ & [74-76] \\
\hline $\begin{array}{l}\text { Transplastomic } \\
\text { technologies }\end{array}$ & $\begin{array}{c}\text { Multigene } \\
\text { expression Highly } \\
\text { productive; Better } \\
\text { biosafety; } \\
\text { site-specific } \\
\text { insertion via } \\
\text { recombination; } \\
\text { Unaffected by } \\
\text { silencing or } \\
\text { position effects }\end{array}$ & $\begin{array}{l}\text { Lacks complex } \\
\text { post-translational } \\
\text { modifications; } \\
\text { Limited protocols } \\
\text { available for } \\
\text { limited species; } \\
\text { generation of lines } \\
\text { are tedious }\end{array}$ & $\begin{array}{l}\text { N-terminal } \\
\text { fragment of } \\
\text { SARS-CoV S } \\
\text { spike protein } \\
\text { (S1)/Tomato and } \\
\text { tobacco }\end{array}$ & $\begin{array}{l}\text { Purified Protein/In } \\
\text { saline and oral } \\
\text { immunization }\end{array}$ & Pre-clinical & $\begin{array}{l}500 \mathrm{mg} \text { of dry } \\
\text { tomato fruit, } 50 \\
\text { mg of dry tobacco } \\
\text { root, 2-week } \\
\text { intervals }\end{array}$ & $\begin{array}{l}\text { The mice } \\
\text { parenterally } \\
\text { primed with } \\
\text { plant-derived } \\
\text { antigen developed } \\
\text { an immune } \\
\text { response after } \\
\text { booster } \\
\text { immunization. }\end{array}$ & $\begin{array}{l}\text { Sera of mice display the } \\
\text { SARS-CoV-specific IgG. }\end{array}$ & {$[73,77]$} \\
\hline
\end{tabular}


The most common approach for expressing a transgene in the plant includes transgene insertion in the genome, and agroinfection by Agrobacterium-mediated transformation is a widely used method since these bacteria can transfer large insert with a highly efficient low number of insertion. It is crucial for stable transformation. The limitation of this method is that gene insertion is random, called a positional effect. Due to this, the expression level might have variations depends on the event, and sometimes it affects the expression of the endogenous gene. However, It has more pros than cons, and with the emergence of new technology, these limitations can be overcome by site-directed insertion by several mechanisms such as genome editing by zinc finger nucleases, TALENs, and CRISPR/Cas9 System, etc. [78].

Site-directed insertion of the foreign DNA into the chloroplast genome resulted from homologous recombination. High protein yield is the plus point of this technology, directly resulting from the transgene's high copy number. There is no report of silencing events and position effects in this method. Moreover, a single transformation event can produce an abundance of proteins $[79,80]$. More detail about plastid-based expression can be found in the given articles [79-81].

Heterologous expression of a protein in plants by delivering virus-based vectors to their target via agroinfection is another approach. This method has a dependence on the DNA/RNA replication mechanism, untranslated regions (UTRs), and promoter efficiency in plant viruses. This method can produce high-yield proteins. For example, GFP yields as high as $5 \mathrm{mg} / \mathrm{g}$ of fresh weight tissue (FWT) are reported [82].

The comoviruses, geminiviruses, potexviruses, tobamoviruses, and tobraviruses were used as a platform for efficient transient expression in plants [83]. In this method, the desired protein purification is essential to remove bacterial residue and other toxins. Hence, this technology is currently limited to nasal vaccine and injection formulation.

\subsection{The Present Situation of Vaccines Produced by Plant Biotechnology That Target Respiratory Disease}

For respiratory disease, many plant-bases vaccine candidates are available for a disease like Bursal disease virus, influenza, Respiratory syncytial virus, Streptococcus pneumoniae, Bacillus anthracis, Mycobacterium tuberculosis, and asthma [84]. These vaccines are safe and can be generated at a low cost by using low-cost bioreactors. It can be administered orally; hence, no antigen purification is needed, saving considerable production costs.

A plant-based vaccine against infectious Bursal disease virus used transient expression of VP2 in Nicotiana benthamiana [85]. Plant-based vaccine for influenza used haemagglutinin (a surface glycoprotein that is involved in influenza virus infection) and M1 protein (most abundant structural matrix protein in the viral core) [86-88]. A pioneering study in the plant by $\mathrm{D}^{\prime}$ Aoust et al. [88] reported the production of enveloped influenza VLPs. It opened the path for the large-scale production of a VPL-based plant-based vaccine for H5N1 influenza with a potential yield of up to 1500 doses per $\mathrm{kg}$ of infiltrated leaves [88,89]. Another study reported the formation of VLPs by expression of HAs from the strains A/Indonesia/5/05 (H5N1) or A/New Caledonia/7/2009 (H1N1). They were transiently expressed in N. benthamiana [90].

Another study reported enhanced immunogenicity of recombinant HA in an enveloped VLP over soluble antigen [91]. Further studies expressed different, HA antigens from A/Brisbane/59/07 [HAB1 (H1)], A/Brisbane/10/07 [HAB1 (H3)], B/Florida/4/06 [HAF1 (B)], and A/California/04/09 [HAC1], respectively) transiently in N. benthamiana. 400-1300 mg protein obtained from $1 \mathrm{Kg}$ of fresh infiltrated leaf tissue [92]. Another study reported good immunogenicity and safety profiles of HAC1 and HAI-05 in animal pre-clinical studies [93].

Clinic trials of the HAC1 vaccine for the H1N1 virus were safe and well tolerable with mild adverse events compared to placebo. This vaccine was also immunogenic with the highest seroconversion rates based on virus microneutralization antibody titers and serum hemagglutination-inhibition [94]. 
One of the studies used a combination of a silica nanoparticle-based $\left(\mathrm{SiO}_{2}\right)$ drug delivery system with a plant-produced H1N1 influenza hemagglutinin antigen (HAC1) and the mucosal adjuvant candidate bis- $\left(3^{\prime}, 5^{\prime}\right)$-cyclic dimeric guanosine monophosphate (c-di-GMP). This vaccine induces systemic humoral immune responses in intratracheally vaccinated mice [95].

The respiratory syncytial virus causes illness in the lower respiratory tract in adults and children [96-99]. Recently, expressing the RSV fusion (F) protein gene in transgenic tomato plants, a fruit-based edible subunit vaccine against RSV was developed. In ripening tomato fruit, the F-gene was expressed under the control of the fruit-specific E8 promoter. Ripe transgenic tomato fruit orally administered to mice led to the induction of mucosal and serum RSV-F specific antibodies [100].

Diseases caused by Streptococcus pneumoniae (the pneumococcus), Haemophilus influen$z a e$, and Neisseria meningitidis are responsible for almost two million deaths each year the children are under five years old $[101,102]$. Disease caused by S. pneumoniae remains high despite the extensive use of pneumococcal vaccines. It is mainly due to the absence of serotypes in the vaccine [103]. A recent study reported that plants could be engineered to synthesize bacterial polysaccharides, and these polysaccharides can provide protective immunity. They also demonstrated this principle using the serotype 3 capsular polysaccharide (a frequently isolated serotype from disease cases) of S. pneumonia [103]. Mice that are immunized with the extracts from recombinant plants were performed better with a lethal dose of pneumococci in a pneumonia mouse model, and the immunized mice display significantly elevated antibodies of serum anti-pneumococcal polysaccharide. This study provides evidence that plant biotechnology tools can successfully synthesize bacterial polysaccharides, and the recombinant polysaccharides produced from them could be used as potential vaccine candidates to protect against life-threatening respiratory infections [103].

Anthrax is another disease for which plant-based vaccines were effective. A Grampositive bacterium, Bacillus anthracis, causes anthrax. Its spores remain viable even in the extreme environment for centuries. Within the host cells, these spores produce threecomponent anthrax toxins: edema factor (EF), lethal factor (LF), and protective antigen (PA) [104]. Inhalation of spores leads to B. anthracis via the respiratory tract leads to severe respiratory distress causing cyanosis, shock, and death [105]. Many studies related to the heterologous expression systems, including bacterial, viral, or plant systems, have been reported for vaccines [106-109]. Due to their natural bio-encapsulation protection from digestive enzymes, plant-based vaccines improve immune response in the gut system by gradually releasing the antigen $[110,111]$. PA is the main virulence factor to cause anthrax. Expression of PA in tobacco and tomato generates lethal toxin neutralizing antibodies in a murine model by intraperitoneal immunization $[112,113]$. Recently PA has been expressed in mustard by Agrobacterium-mediated transformation since mustard is commonly used as a stem and leaf vegetable and fodder meant for cattle in various parts of the world. In orally immunized groups, a specific mucosal immune response was observed.

Furthermore, in-vitro lethal toxin neutralizing potential indicated by the antibodies conferred in-vivo protection against toxin challenge. The immunoprotective response was observed in mice during oral immunization [114]. They use agroinfiltration plant transient expression systems for engineered, expressed, purified, and characterized full-length PA (pp-PA83) in tobacco plants. Immunization with these vaccines protected all the rabbits from the lethal aerosolized B. anthracis. The vaccine antigen formulated with Alhydrogel retained immunogenicity even after two-week storage at $4{ }^{\circ} \mathrm{C}$ and was stable (essential for clinical use) [115]. Anthrax protective antigen (PA-D4) domain-4 epitope has a vital role in enhancing protective immunity against virulent $B$. anthracis. One study successfully reported a recombinant protein that comprised the antigenic PA-D4 integration into the c/e1 loop of HBcAg in transgenic tobacco. Plant-derived purified HB/PA-D4 protein injected into mice, and its sera display significant anti-HBcAg and PA-specific IgG titers [116]. 
Plant biotechnology-based vaccines are also made to prevent the infectious disease tuberculosis. Mycobacterium tuberculosis causes tuberculosis [117]. It can transmit from human to human via droplets expelled into the air via an infectious person. Death caused by TB even exceeded HIV, making it a more significant epidemic than expected. To date, seven oral plant biotechnology-based TB vaccines have been extensively evaluated either in experimental or pre-clinical and phase I clinical trials [117]. In Potato, Ag85B, ESAT-6, MPT64, and MPT83 antigens are expressed [118]; in tobacco, Acr, and Ag85B antigens are expressed [119]; in Arabidopsis thaliana, ESAT-6 fused to LTB and antigens are expressed [120,121]; in carrot CFP10 and ESAT-6 antigens are expressed [122]; and in lettuce and tobacco, Mtb72F (Mtb32/Mtb39) and ESAT-6 fused to CTB and its antigens expression in the chloroplast [123] (Table 4).

Asthma is also a chronic inflammatory disorder, where a plant-based vaccine is effective. Asthma affects about 300 million people worldwide. It is estimated that by 2025 asthma will affect an additional 100 million people [126]. In one study, a genetically modified narrow-leaf lupin (Lupinus angustifolius L.) expressing a potential allergen (sunflower seed albumin) (SSA-lupin) gene was examined whether it can suppress the development of asthma. The result indicated that SSA-lupin consumption promoted an Ag-specific IgG2a $\mathrm{Ab}$ response via $\mathrm{CD} 4^{+} \mathrm{CD}_{45 \mathrm{RB}^{\text {low }}} \mathrm{T}$ Cell and IFN- $\gamma$-dependent mechanism [124].

In another study, transgenic Tg rice plants express in their seeds a fragment (residues 45-145) of Der p 1 containing the significant human and mouse T-cell epitopes. Oral administration of the $\mathrm{Tg}$ rice seeds to mice inhibits the allergen-specific IgE responses and allergen-specific T helper 2 (Th2) cytokine synthesis (IL-4, IL-5, and IL-13). This induction of oral tolerance was linked with inhibition of bronchial hyper-responsiveness (BHR) [125]. In tobacco leaves, the recombinant chimeric allergen R8 was successfully expressed. In the herbaceous leaf extracts, a pro-peptide was observed. This protein displays properties the same as tobacco with respect to IgE immune reactivity or the parental allergen ProDer $\mathrm{f} 1$ that is expressed in Escherichia coli [127].

Since SARS-CoV2 is also a respiratory disease, developing a new plant-based vaccine study mentioned above can significantly impact it. There are already some applications by Medicago Inc., using the same virus-like particle platform, which it has used for a plant-based vaccine for H5N1 influenza in the study mentioned earlier.

Plant biotechnology-based vaccines are becoming a reality, even though their progress has been slower than expected. It is particularly true in oral vaccines, having the main drawbacks of poor reproducibility, a question mark in antigen stability, and bioavailability $[128,129]$.

Plant biotechnology allows foreign protein expression in plants and projects a shortterm approach for a potential vaccine candidate for SARS-CoV-2. The method of this expression will depend upon the nature of the targeted antigen. In the following section, we have discussed the idea of using a plant biotechnology bases platform as a possible approach for SARS-CoV-2 vaccine development (Figure 2). 
Table 4. Plant-based vaccines against respiratory disease.

\begin{tabular}{|c|c|c|c|c|c|c|c|}
\hline Vaccine Candidate & Plant & Antigen & Animal & Route of Inoculation/Doses & Degree of Protection & Immunological Data & Reference \\
\hline Bursal disease virus & Tobacco & VP2/extracted & $\begin{array}{l}\text { Embryonated eggs of } \\
\text { White Leghorn } \\
\text { chickens }\end{array}$ & $\begin{array}{l}\text { Intramuscular/12 } \mu \mathrm{g} \text { of VP2 } \\
\text { and equal volume of } \\
\text { Freund's adjuvant and } 1 \% \\
\text { total volume of Tween } 40\end{array}$ & $\begin{array}{l}\text { Plant-derived VP2 } \\
\text { elicited an antibody } \\
\text { response with } \\
\text { neutralizing activity }\end{array}$ & $\begin{array}{l}\text { VP2 produced in } \\
\text { plants can elicit an } \\
\text { appropriate immune } \\
\text { response in chickens }\end{array}$ & [85] \\
\hline $\begin{array}{c}\text { Respiratory } \\
\text { syncytial virus }\end{array}$ & Tomato & F-gene/extracted & $\mathrm{BALB} / \mathrm{c}$ mice & $\begin{array}{l}\text { Oral immunization } / \text { each } \\
\text { mouse was given } 5-7 \mathrm{~g} \text { of } \\
\text { ripe tomato fruit containing } \\
\text { recombinant RSV-F protein } \\
\text { and consumed 3-4 g. }\end{array}$ & $\begin{array}{l}\text { Transgenic-fruit-derived } \\
\text { RSV-F antigen primed } \\
\text { a mixed type 1-2 } \\
\text { T-helper cell } \\
\text { immune response } \\
\text { and further that this } \\
\text { RSV-boost-induced } \\
\text { response } \\
\text { showed some bias } \\
\text { towards the Th1-type }\end{array}$ & $\begin{array}{l}\text { Ripe transgenic } \\
\text { tomato administered } \\
\text { to mice orally that } \\
\text { led to the elevation of } \\
\text { mucosal and serum } \\
\text { RSV-F specific } \\
\text { antibodies }\end{array}$ & [100] \\
\hline $\begin{array}{l}\text { Streptococcus } \\
\text { pneumoniae }\end{array}$ & Tobacco & $\begin{array}{l}\text { Serotype } 3 \text { capsular } \\
\text { polysaccha- } \\
\text { ride/extracted }\end{array}$ & MF1 female mice & $\begin{array}{l}\text { Intraperitonea } 1 / 2 \mu \mathrm{g} \\
\text { plant-derived pneumococcal } \\
\text { polysaccharide per mouse in } \\
67 \mu \mathrm{L} \text { PBS and } 33 \mu \mathrm{L} \text { Inject } \\
\text { alum adjuvant (Pierce, } \\
\text { Rockford, IL, USA) }\end{array}$ & $\begin{array}{l}\text { None of the fifteen } \\
\text { animals given wild-type } \\
\text { extract were alive ten } \\
\text { days after the challenge, } \\
\text { whereas eight of the } \\
\text { fourteen immunized } \\
\text { with transgenic } \\
\text { extract survived }\end{array}$ & $\begin{array}{l}\text { Immunized mice had } \\
\text { significantly elevated } \\
\text { levels of serum } \\
\text { anti-pneumococcal } \\
\text { polysaccharide } \\
\text { antibodies. }\end{array}$ & [103] \\
\hline Bacillus anthracis & $\begin{array}{l}\text { Tobacco, Tomato, } \\
\text { and Mustard }\end{array}$ & $\begin{array}{l}\text { Protective antigen } \\
\text { (PA)/extracted }\end{array}$ & BALB/c mice & $\begin{array}{c}\text { Intraperitoneal/Protein } \\
\text { extracted from tomato leaves } \\
\text { was mixed with complete } \\
\text { Freund's adjuvant (for the } \\
\text { first dose) and incomplete } \\
\text { Freund's adjuvant (for } \\
\text { subsequent doses) in a ratio } \\
\text { of 1:1. }\end{array}$ & $\begin{array}{l}\text { The PA expressed in } \\
\text { nuclear transgenic } \\
\text { tomato plants was able } \\
\text { to generate an } \\
\text { antibody-mediated } \\
\text { immune response. }\end{array}$ & $\begin{array}{l}\text { A specific mucosal } \\
\text { immune response } \\
\text { was observed }\end{array}$ & {$[112,113]$} \\
\hline
\end{tabular}


Table 4. Cont.

\begin{tabular}{|c|c|c|c|c|c|c|c|}
\hline Vaccine Candidate & Plant & Antigen & Animal & Route of Inoculation/Doses & Degree of Protection & Immunological Data & Reference \\
\hline $\begin{array}{l}\text { Mycobacterium } \\
\text { tuberculosis }\end{array}$ & $\begin{array}{l}\text { Potato, Tobacco, } \\
\text { Carrot, } \\
\text { Arabidopsis, and } \\
\text { Lettuce }\end{array}$ & $\begin{array}{l}\text { Ag85B, ESAT-6, } \\
\text { MPT64, MPT83, Acr, } \\
\text { Ag85B, ESAT-6 fused } \\
\text { to LTB, CFP10, } \\
\text { ESAT-6, Mtb72F, and } \\
\text { ESAT-6 fused to } \\
\text { CTB/extracted }\end{array}$ & $\begin{array}{l}\text { C57BL/6 mice, } \\
\text { BALB/c mice, } \\
\text { Female ICR mice, } \\
\text { Seryi velikan } \\
\text { strain rabbits. }\end{array}$ & $\begin{array}{c}\text { Orally, intranasal, } \\
\text { intraperitoneal/BCG group } \\
\text { were fed orally with } \\
1.8 \times 10^{7} \text { CFU BCG in } \\
100 \mu \mathrm{L} \text { saline per mouse. The } \\
\text { mice of the combined-plant } \\
\text { vaccine group were fed with } \\
1 \mathrm{ml} \text { of the concentrated } \\
\text { transgenic potato extract. } \\
\text { Mice were immunized } \\
\text { subcutaneously with } 100 \mu \mathrm{L} \\
\text { of BCG administered at the } \\
\text { base of the tail or with } 10 \mu \mathrm{g} \\
\text { TB-RICs preparation (in } \\
30 \mu \mathrm{L} \text { ) intranasal, under } \\
\text { isoflurane anesthesia. Test } \\
\text { animals were provided with } \\
3 \mathrm{~g} \text { of the mix (92.6 } \mu \mathrm{g} \text { of } \\
\text { plant-made LTB-ESAT-6). } \\
\text { Feed treatments were given } \\
\text { on days } 0,7,14 \text {, and } 28 .\end{array}$ & $\begin{array}{l}\text { Generating } \\
\text { antigen-specific, } \\
\text { Th1 response }\end{array}$ & Antigens expression & [118-123] \\
\hline Asthma & Lupin & SSA-lupin/extracted & BALB/c mice & $\begin{array}{l}\text { Intraperitoneal } / 50 \mu \mathrm{g} \text { of SSA } \\
\text { or OVA in alum }(1 \mathrm{mg} / \mathrm{mL}) \\
\text { dissolved in PBS (final } \\
\text { volume } 200 \mu \mathrm{L} \text { ). On days } 14 \\
\text { and } 16 . \mathrm{B} \text {, Lupin, and } \\
\text { SSA-lupin induced systemic } \\
\text { sensitization and DTH } \\
\text { responses. }\end{array}$ & $\begin{array}{l}\text { GM plant-based vaccine } \\
\text { can promote a protective } \\
\text { immune response and } \\
\text { attenuate experimental } \\
\text { asthma }\end{array}$ & $\begin{array}{l}\text { Consumption of } \\
\text { SSA-lupin promoted } \\
\text { the elevation of an } \\
\text { Ag-specific IgG2a Ab } \\
\text { response through } \\
\text { CD4+CD45RBlow T } \\
\text { Cell and IFN- } \gamma \\
\text {-dependent } \\
\text { mechanism }\end{array}$ & [124] \\
\hline
\end{tabular}


Table 4. Cont.

\begin{tabular}{|c|c|c|c|c|c|c|c|}
\hline Vaccine Candidate & Plant & Antigen & Animal & Route of Inoculation/Doses & Degree of Protection & Immunological Data & Reference \\
\hline $\begin{array}{l}\text { Bronchial hyper- } \\
\text { responsiveness }\end{array}$ & Rice & Der $\mathrm{p} 1 /$ purified & $\mathrm{BALB} / \mathrm{c}$ mice & $\begin{array}{l}\text { Orally vaccinated by feeding } \\
6-8 \text {-week-old female } \\
\text { BALB/c mice were orally } \\
\text { vaccinated by feeding } 0.5 \text { or } \\
5 \mathrm{mg} \text { purified recombinant } \\
\text { Der P1 dissolved in PBS on } \\
\text { day } 1 \text {. Mice were given four } \\
\text { intraperitoneal injections of } \\
2 \mu \mathrm{g} \text { of recombinant Der } \mathrm{p} 1 \\
\text { adsorbed to alum adjuvant. }\end{array}$ & $\begin{array}{l}\text { Prophylactic efficacy of } \\
\text { oral vaccination with Tg } \\
\text { rice seeds accumulated } \\
\text { Der p } 1(45-145) \text { in a } \\
\text { mouse model of asthma, } \\
\text { reducing allergic airway } \\
\text { inflammation and } \\
\text { reduced BHR. }\end{array}$ & $\begin{array}{l}\text { Oral administration } \\
\text { of the Tg rice seeds to } \\
\text { mice inhibits the } \\
\text { allergen-specific IgE } \\
\text { responses and } \\
\text { allergen-specific } \mathrm{T} \\
\text { helper } 2 \text { (Th2) } \\
\text { cytokine synthesis } \\
\text { (IL-4, IL-5, and IL-13) }\end{array}$ & [125] \\
\hline
\end{tabular}




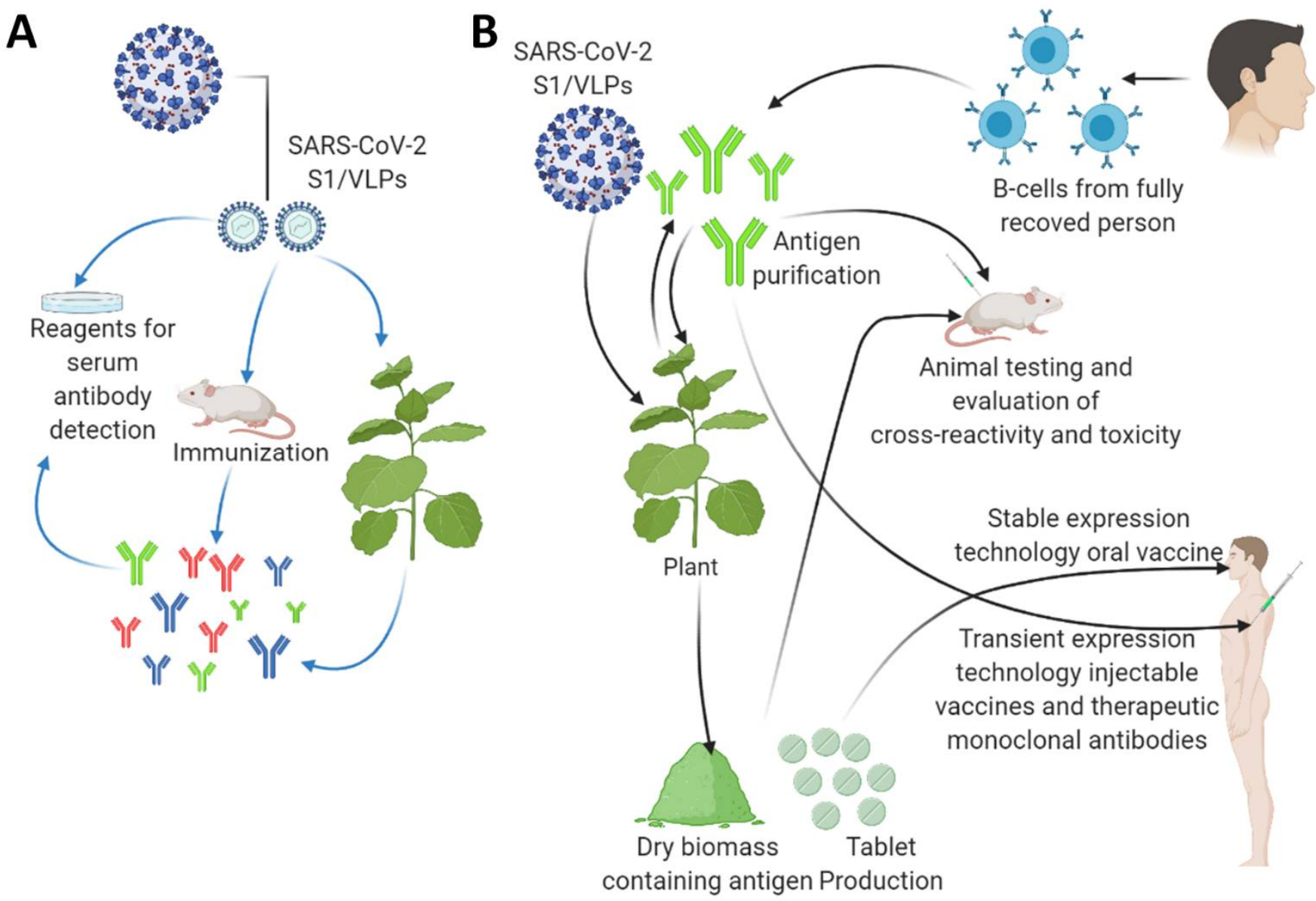

Figure 2. The applications of plant biotechnology-based production of diagnostic reagents and vaccine candidates against the SARS-CoV2. (A) Plant-based production of diagnostic reagents indicated by blue arrows. (B) Plant-based production of vaccine candidates against the SARS-CoV2 indicated by black arrows. A tobacco plant is shown as a model plant for both transient expression and stably transformed transgenic plants as a large-scale production platform. Genetic engineering approaches express target antigens by either stably or transiently transformation, enabling scientists to use different immunization approaches. The transient transformation method enables high antigen protein yields in the transformed plants purified to obtain injectable vaccines or therapeutic monoclonal antibodies. In a stable genetic transformation method, the edible plant species can provide oral vaccine formulations such as; capsules or tables with antigens from freeze-dried leaves. They can also be applied as a boosting agent. This figure is prepared by using Biorender (https://biorender.com/, accessed on 12 June 2021).

\section{Scope of SARS-CoV-2 Vaccine Development Using Plant Biotechnology Platform}

Nanoparticles (NPs) and virus-like particles (VLPs) are the protein structures that have similarities with native viruses but do not contain a viral genome nor have any infectious ability, thus creating a safer platform for vaccine candidates [130]. Both NPs and VLPs constitute self-assembling proteins that display the epitope of interest at a higher density at their surface. Nanoparticles must have the antigenic epitopes repetitive and so that the innate humoral immune system and B cells are activated [131-133]. NPs/VLPs support antigen uptake by antigen-presenting cells (APCs), enhancing the immune system's adaptive arms [134]. In the 21st century, many platforms for NPs/VLPs design have been evolved, including the usage of site-specific ligations-driven covalent links of individual folded proteins, viral core proteins, and non-covalent intramolecular formation of de novo protein nanostructure via intermolecular interactions. Both self-assembled protein NPs and VLPs offer highly stable, ordered, and monodisperse vaccine formulations and 
upscale production with bio farming. For the new vaccine development, NPs/VLPs are currently recognized as the most studied promising molecular carriers [130]. To develop VLPs Medicago Inc. (Quebec City, QC, Canada) used the Nicotiana benthamiana plant [135]. Medicago's plant-derived COVID-19 vaccine candidate along with GlaxoSmithKline's (GSK) pandemic adjuvant have entered into the phase $2 / 3$ clinical trials. Medicago's plantderived vaccine candidate against COVID-19 uses Coronavirus-Like-Particle (CoVLP) technology in which vaccine composed of recombinant spike (S) glycoprotein and is expressed as virus-like-particles (VLPs). It is co-administered with GSK's adjuvant. Two doses of 3.75 micrograms of CoVLP are administered 21 days apart. Data shows that the combination of the vaccine candidate and GSK's pandemic adjuvant-induced a significant humoral immune response after two doses. Similar antibody responses were observed in younger and middle-aged adults, as well as elderly adults. (https://www.medicago.com/ en/newsroom/; https://ir.ibioinc.com/press-releases; https://news.cision.com/expres2 ion-biotechnologies, accessed on 12 June 2021) [136]. Kentucky BioProcessing, Inc. (KBP) (formally known as Large Scale Biology Corp.) candidate vaccine, COVID-19 Subunit Vaccine KBP-201, is in the 2nd phase of clinical trials. They have used Nicotiana benthamiana as a host plant/expression system. Both candidate vaccines have two doses scheduled after 21 days gap. They can be administered via the intramuscular route (Table 5). There are four other candidate vaccines from iBio, Inc. (New York, NY, USA), Akdeniz University (Turkey), Shiraz University (Iran), and Baiya Phyto-pharm/Chula Vaccine Research Center (Thailand) that are in the pre-clinical stage and have used the plant as an expression system. Many reports explain the role of NPs in SARS-CoV-2 in detail [136-142]. 
Table 5. Current status of WHO listed plant-based vaccine candidates for COVID-19 under trial stages.

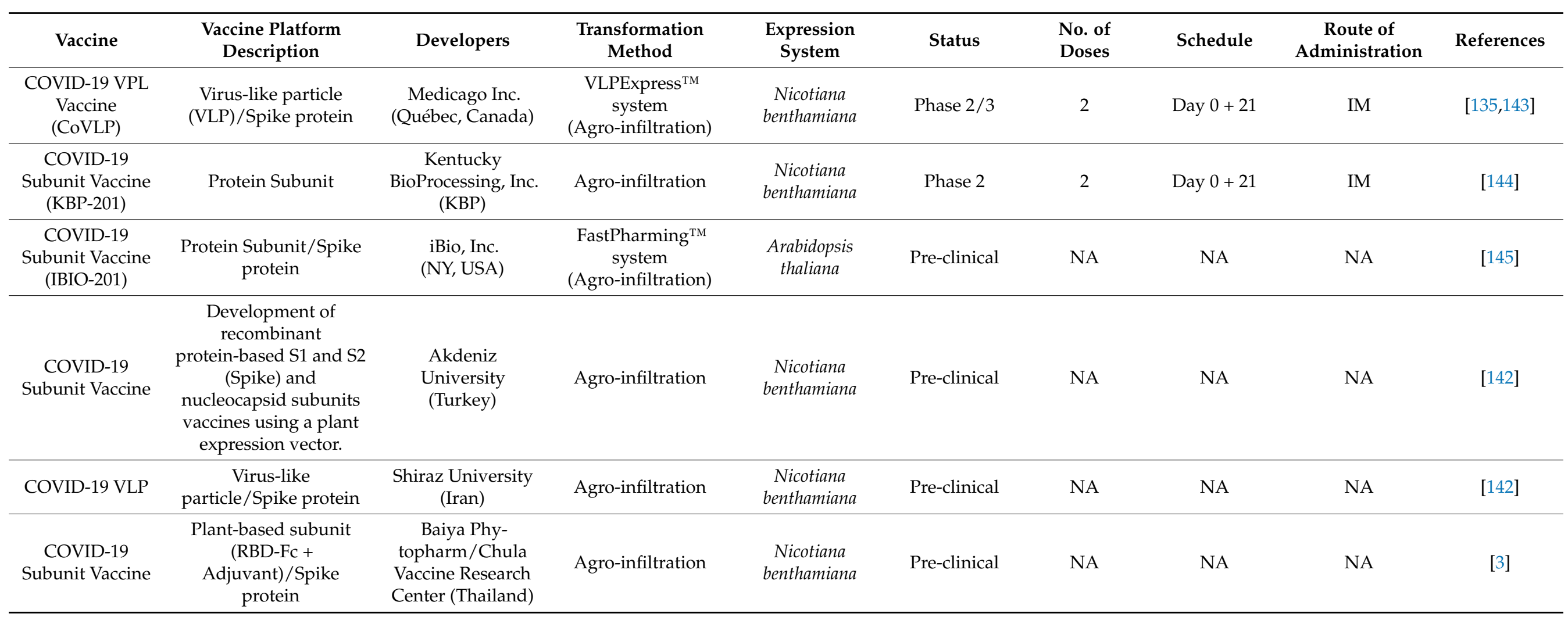


For the production of VLPs, several studies target Poliovirus, hepatitis B virus, human papillomavirus, influenza virus, Norwalk virus, human immunodeficiency retrovirus 1, rift valley fever virus, and foot and mouth disease virus [132,146-158]. Earlier experience of forming VLPs for MERS and SARS-CoV-1 antigens heterologous expressed in recombinant systems provides us the best platform for developing a vaccine against SARS-CoV-2. A study reported that in morphology, developed VLPs were similar to the virions of SARS$\mathrm{CoV}-1$. Another report stated that envelope proteins (E) and membrane (M) are sufficient enough for the efficient formation of virus-like particles, and they could be visualized by electron microscopy [159]. VLPs formed by membrane proteins of different origins activated immature dendritic cells (DCs) and enhanced the secretion of cytokines and co-stimulatory molecules' expression [160].

Mucosal routes have emerged as attractive and promising routes for the vaccination of respiratory diseases. Mucosal immune response for VLPs is an essential aspect of vaccine success. In one study, mice were immunized with VLPs plus cytosine-phosphate guanosine (CpG) and VLPs intranasally. Both of them induced IgG specified to SARS-CoV1 [161].

Given that HA protein expression in plant-made VLPs vaccine successful, similarly, it is believed that for the development of SARS-CoV-2 VLPs, S protein expression might be necessary. Considering this, targeting the trans-Golgi secretion route by nuclear expression might yield a protein that, via secretion and glycosylation process, can produce VLPs for SARS-CoV-2 [162]. Forty-seven plant-based candidate VLPs vaccine has been developed for a wide range of disorders [163].

\section{Concluding Remarks and Future Direction}

There are a few risks that might be involved with the plant biotechnology platformbased vaccine [164]. Their risks include (1) Oral tolerance; if the antigen is delivered too frequently, the mucosal immune system becomes desensitized to the candidate vaccine, and the vaccination might no longer tackle susceptibility to the target disease. (2) Allergenicity; compared to the natural pathogen in plants, a transgenic product might be undergone by different post-translational modifications, which might induce new allergenic responses in the host during vaccination. Along with this, the use of oral adjuvants for mucosal linings stimulation might induce hypersensitive responses to other food proteins $[165,166]$. (3) Gene transfer; transfer of the antigen to the conventional food supply through genetic engineering could lead to oral tolerance. (4) Detrimental effects on the environment; natural loss and degradation of a gene during selection within the environmental system. The transgene is randomly inserted into the genome during gene transfer, which can lead to positional effects. These events make expression levels unpredictable, and the loss of endogenous genes is also a possibility that might leads to toxicity or allergenicity implications. Advancements in technologies can solve these limitations by providing alternative methods to achieve site-directed mutation through many mechanisms [78]. (5) Inconsistent dosage; an insufficient amount of antigen might not produce the desired immune response needed to protect against the deadly disease. Incorrect frequency or wrong dosage could lead to tolerance and reduce vaccine effectiveness in some candidates $[167,168]$. To overcome this limitation, proper clinical trials in animals and humans must determine the doses to generate a proper immune response.

COVID-19 outbreak led to a global health emergency that demands new vaccines to cope with this pandemic. Plant biotechnology-based vaccine candidates offer an alluring approach for containing this virus. The available expression platform offers relevant directions for developing a candidate vaccine for COVID-19. The deconstructed viral vectors transient expression system is one of the alternative approaches for vaccine production where the tobacco as a host plant will allow for fast exploitation of plants as efficient largescale biofactories for injectable vaccine candidates. A major disadvantage of this strategy is the potential loss of exogenous genes and ultimately loss of systemic infectivity. However, this can be prevented by using a subgenomic promoter derived from a different virus. It will lead to heterologous genetic recombination. Currently, six front-runner plant-based 
vaccines are based on this platform (Table 5). VLPs vaccine is another alternative option that provides an attractive approach for producing safe and efficient vaccines, which lacks replicative capacity, preserve antigenic determinant, and have high immunogenicity. VLPs based vaccines platform cannot be used for all types of viruses, which might be a major drawback for this technology. However, if its advantage is taken into consideration, the VLPs vaccine has vast potential. VLPs platform already has a proven track record in the case of earlier SARS-CoV-1. Hence, VLPs development based on different SARS-CoV-2 structural proteins is an excellent approach against COVID-19. Another approach is to develop vaccines based on edible plant species that are transformed at the nuclear level and administered as oral vaccines. It will provide mucosal immunity.

In 2020, the market size of global plant-based vaccines was estimated to be valued at 927.0 million USD, and in the next six years, it is expected to witness a growth rate of over $11.7 \%$. Existing key players and new entrants in the plant-based vaccines market now focus on extensive clinical trial studies to develop plant-based vaccines for numerous therapeutic applications, including the COVID-19 vaccine. For example, Medicago Inc., a clinical-stage Canadian biotechnology company, uses plant-based technologies to develop and produce many novel vaccines and antibodies by cultivating several tobacco plants (Nicotiana tabacum) at its Durham's Research Triangle Park in North America. This facility will be used in the testing and large-scale production of the flu vaccine. To develop the flu vaccine, Medicago conducted phase 3 clinical trials in March 2018. It is expected to be launched in the market soon during influenza season.

It requires almost five to six weeks to produce a plant-based vaccine compared to a five to six-month period preparing the vaccine in chicken eggs, which the various vaccine manufacturers are currently practicing. Along with these developments, monoclonal antibody production in plants can also provide another alternative plasma transfusion strategy. Antibodies developed in plants will be affordable and have safer intravenous treatment for critically ill patients (Figure 2). There are already approved plant-based vaccines for influenza that give hope to the potential of plant-based anti-COVID-19 vaccine. The Coalition for Epidemic Preparedness Innovations (CEPI) estimated that global vaccine manufacturing capacity would be only 2-4 billion doses annually, and by 2023-2024, not enough vaccines can be manufactured to meet global demands. This capacity might also be product-specific, along with some limitations: for example, whole-inactivated virus vaccines must be manufactured in a facility with biosafety level 3-capability. In addition to this administrative, the regulatory process of licensing, technology transfer, and the scale-up of vaccine manufacturing, purification or formulation might be time-consuming, and fulfilling these requirements in a time-bound manner will remain challenging. A plantbased vaccine platform can fill the gap and help maintain the demand/supply ratio. The coming years will be crucial to see the real potential of a plant-based vaccine for COVID-19 or any other pandemic.

Author Contributions: M.K. designed the study; M.K. wrote the manuscript with critical inputs from S.-M.C.; N.K., N.T., S.K.B., G.G., B.M.M., G.D.S., H.A., D.S.K. and X.D. who gave valuable input to this manuscript; M.K. and S.-M.C. acquired funding. All authors have read and agreed to the published version of the manuscript.

Funding: Dongguk University 2020 to MK, and Korea Institute of Planning and Evaluation for Technology in Food, Agriculture, Forestry, (317011-04-3-HD020) to S.-M.C.

Acknowledgments: M.K. acknowledges Dongguk University, Seoul, South Korea, for Assistant Professorship 2020-2022. S.-M.C; acknowledge Korea Institute of Planning and Evaluation for Technology in Food, Agriculture, Forestry through the Agri-Bio Industry Technology Development Program funded by the Ministry of Agriculture, Food and Rural Affairs (MAFRA) (317011-04-3-HD020).

Conflicts of Interest: Authors declare no conflict of interest. 


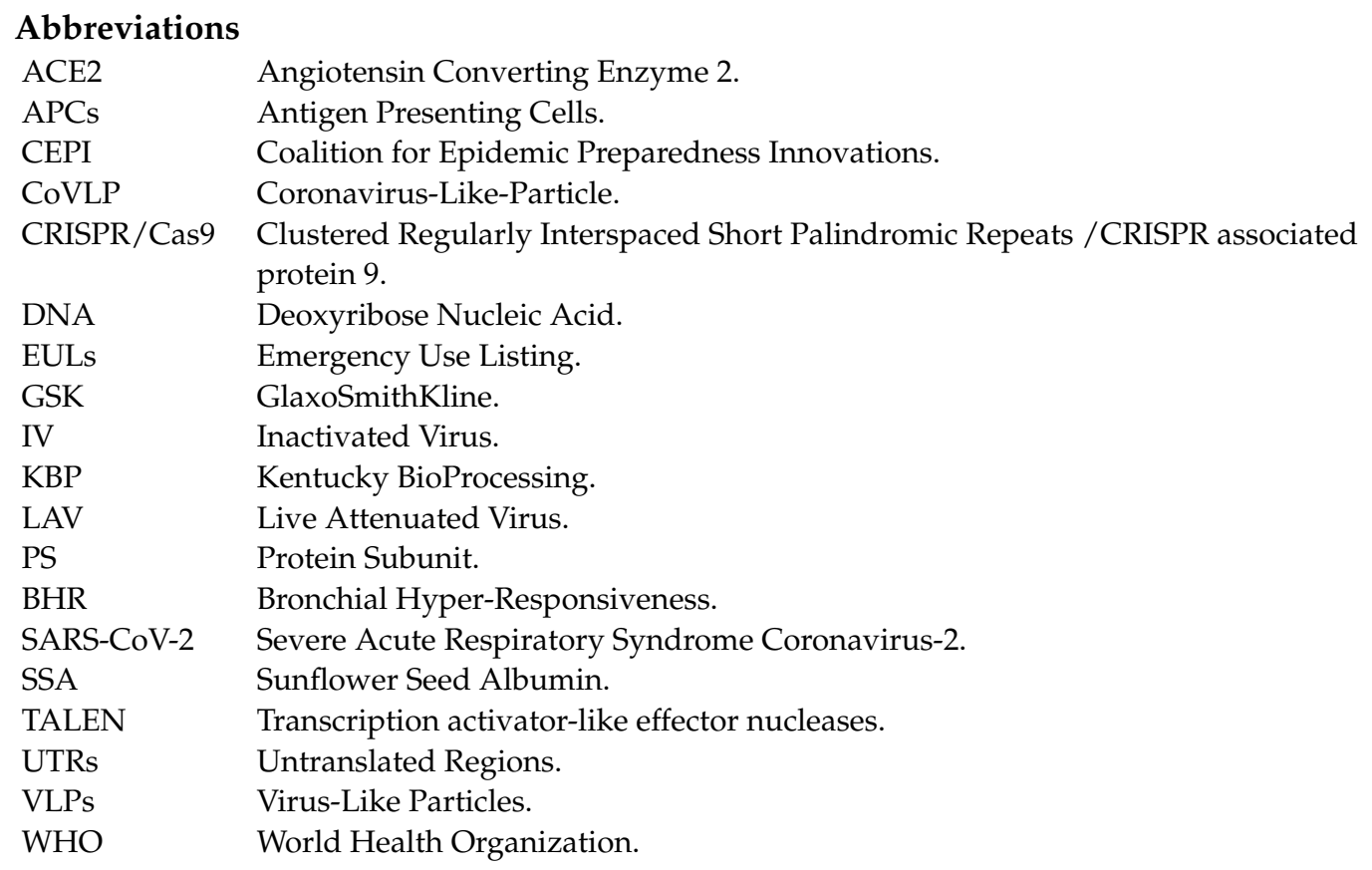

\section{References}

1. Xu, X.T.; Chen, P.; Wang, J.F.; Feng, J.N.; Zhou, H.; Li, X.; Zhong, W.; Hao, P. Evolution of the novel coronavirus from the ongoing Wuhan outbreak and modeling of its spike protein for risk of human transmission. Sci. China Life Sci. 2020, 63, 457-460. [CrossRef]

2. WHO (World Health Organization). Available online: https://www.who.int/emergencies/diseases/novel-coronavirus-2019 (accessed on 14 June 2021).

3. WHO (World Health Organization). Available online: https://www.who.int/publications/m/item/draft-landscape-of-covid-19 -candidate-vaccines (accessed on 14 June 2021).

4. Mitja, O.; Clotet, B. Use of antiviral drugs to reduce COVID-19 transmission. Lancet Glob. Health 2020, 8, E639-E640. [CrossRef]

5. Hoffmann, M.; Schroeder, S.; Kleine-Weber, H.; Muller, M.A.; Drosten, C.; Pohlmann, S. Nafamostat Mesylate Blocks Activation of SARS-CoV-2: New Treatment Option for COVID-19. Antimicrob. Agents Chemother. 2020, 64. [CrossRef]

6. Engelmann, C.; Fischer, J.; Krohn, S.; Herber, A.; Boehlig, A.; Deichsel, D.; Boehm, S.; Berg, T. Genetic polymorphism of mannose binding lectin 2: A potential new risk factor for spontaneous bacterial peritonitis in cirrhotic patients. Hepatology 2014, 60, 483a.

7. Gurwitz, D. Angiotensin receptor blockers as tentative SARS-CoV-2 therapeutics. Drug Dev. Res. 2020, 81, 537-540. [CrossRef] [PubMed]

8. Speth, R.C. Response to recent commentaries regarding the involvement of angiotensin-converting enzyme 2 (ACE2) and renin-angiotensin system blockers in SARS-CoV-2 infections. Drug Dev. Res. 2020, 81, 643-646. [CrossRef] [PubMed]

9. Shen, C.G.; Wang, Z.Q.; Zhao, F.; Yang, Y.; Li, J.X.; Yuan, J.; Wang, F.X.; Li, D.L.; Yang, M.H.; Xing, L.; et al. Treatment of 5 Critically Ill Patients With COVID-19 With Convalescent Plasma. JAMA 2020, 323, 1582-1589. [CrossRef] [PubMed]

10. Gao, Q.; Bao, L.L.; Mao, H.Y.; Wang, L.; Xu, K.W.; Yang, M.N.; Li, Y.J.; Zhu, L.; Wang, N.; Lv, Z.; et al. Development of an inactivated vaccine candidate for SARS-CoV-2. Science 2020, 369, 77. [CrossRef]

11. van Riel, D.; de Wit, E. Next-generation vaccine platforms for COVID-19. Nat. Mater. 2020, 19, 810-812. [CrossRef]

12. See, R.H.; Petric, M.; Lawrence, D.J.; Mok, C.P.Y.; Rowe, T.; Zitzow, L.A.; Karunakaran, K.P.; Voss, T.G.; Brunham, R.C.; Gauldie, J.; et al. Severe acute respiratory syndrome vaccine efficacy in ferrets: Whole killed virus and adenovirus-vectored vaccines. J. Gen. Virol. 2008, 89, 2136-2146. [CrossRef]

13. Kobinger, G.P.; Figueredo, J.M.; Rowe, T.; Zhi, Y.; Gao, G.P.; Sanmiguel, J.C.; Bell, P.; Wivel, N.A.; Zitzow, L.A.; Flieder, D.B.; et al. Adenovirus-based vaccine prevents pneumonia in ferrets challenged with the SARS coronavirus and stimulates robust immune responses in macaques. Vaccine 2007, 25, 5220-5231. [CrossRef]

14. Qu, D.; Zheng, B.J.; Yao, X.; Guan, Y.; Yuan, Z.H.; Zhong, N.S.; Lu, L.W.; Xie, J.P.; Wen, Y.M. Intranasal immunization with inactivated SARS-CoV (SARS-associated coronavirus) induced local and serum antibodies in mice. Vaccine 2005, $23,924-931$. [CrossRef]

15. Kotomina, T.; Isakova-Sivak, I.; Matyushenko, V.; Kim, K.H.; Lee, Y.; Jung, Y.J.; Kang, S.M.; Rudenko, L. Recombinant live attenuated influenza vaccine viruses carrying CD8 T-cell epitopes of respiratory syncytial virus protect mice against both pathogens without inflammatory disease. Antiviral Res. 2019, 168, 9-17. [CrossRef] [PubMed]

16. Wang, F.B.; Patel, D.K.; Antonello, J.M.; Washabaugh, M.W.; Kaslow, D.C.; Shiver, J.W.; Chirmule, N. Development of an adenovirus-shedding assay for the detection of adenoviral vector-based vaccine and gene therapy products in clinical specimens. Hum. Gene Ther. 2003, 14, 25-36. [CrossRef]

17. Jiang, S.B. Don't rush to deploy COVID-19 vaccines and drugs. Nature 2020, 579, 321. [CrossRef] [PubMed] 
18. Salvatori, G.; Luberto, L.; Maffei, M.; Aurisicchio, L.; Roscilli, G.; Palombo, F.; Marra, E. SARS-CoV-2 SPIKE PROTEIN: An optimal immunological target for vaccines. J. Transl. Med. 2020, 18. [CrossRef]

19. Walls, A.C.; Park, Y.J.; Tortorici, M.A.; Wall, A.; McGuire, A.T.; Veesler, D. Structure, Function, and Antigenicity of the SARS-CoV-2 Spike Glycoprotein. Cell 2020, 181, 281. [CrossRef] [PubMed]

20. Armbruster, N.; Jasny, E.; Petsch, B. Advances in RNA Vaccines for Preventive Indications: A Case Study of a Vaccine against Rabies. Vaccines 2019, 7, 132. [CrossRef]

21. Zhang, N.N.; Li, X.F.; Deng, Y.Q.; Zhao, H.; Huang, Y.J.; Yang, G.; Huang, W.J.; Gao, P.; Zhou, C.; Zhang, R.R.; et al. A Thermostable mRNA Vaccine against COVID-19. Cell 2020, 182, 1271-1283 e1216. [CrossRef] [PubMed]

22. Tai, W.; Zhang, X.; Drelich, A.; Shi, J.; Hsu, J.C.; Luchsinger, L.; Hillyer, C.D.; Tseng, C.K.; Jiang, S.; Du, L. A novel receptor-binding domain (RBD)-based mRNA vaccine against SARS-CoV-2. Cell Res. 2020, 10, 932-935. [CrossRef] [PubMed]

23. Corbett, K.S.; Flynn, B.; Foulds, K.E.; Francica, J.R.; Boyoglu-Barnum, S.; Werner, A.P.; Flach, B.; O'Connell, S.; Bock, K.W.; Minai, M.; et al. Evaluation of the mRNA-1273 Vaccine against SARS-CoV-2 in Nonhuman Primates. N. Engl. J. Med. 2020. [CrossRef]

24. Egan, K.P.; Hook, L.M.; Naughton, A.; Pardi, N.; Awasthi, S.; Cohen, G.H.; Weissman, D.; Friedman, H.M. An HSV-2 nucleosidemodified mRNA genital herpes vaccine containing glycoproteins $\mathrm{gC}, \mathrm{gD}$, and gE protects mice against HSV-1 genital lesions and latent infection. PLoS Pathog. 2020, 16, e1008795. [CrossRef]

25. Jackson, L.A.; Anderson, E.J.; Rouphael, N.G.; Roberts, P.C.; Makhene, M.; Coler, R.N.; McCullough, M.P.; Chappell, J.D.; Denison, M.R.; Stevens, L.J.; et al. An mRNA Vaccine against SARS-CoV-2-. Preliminary Report. N. Engl. J. Med. 2020, 383, $1920-1931$. [CrossRef]

26. Ahammad, I.; Lira, S.S. Designing a novel mRNA vaccine against SARS-CoV-2: An immunoinformatics approach. Int. J. Biol. Macromol. 2020, 162, 820-837. [CrossRef]

27. Verbeke, R.; Lentacker, I.; De Smedt, S.C.; Dewitte, H. Three decades of messenger RNA vaccine development. Nano Today 2019, 28, 100766. [CrossRef]

28. Polack, F.P.; Thomas, S.J.; Kitchin, N.; Absalon, J.; Gurtman, A.; Lockhart, S.; Perez, J.L.; Marc, G.P.; Moreira, E.D.; Zerbini, C.; et al. Safety and Efficacy of the BNT162b2 mRNA Covid-19 Vaccine. N. Engl. J. Med. 2020, 383, 2603-2615. [CrossRef]

29. Baden, L.R.; El Sahly, H.M.; Essink, B.; Kotloff, K.; Frey, S.; Novak, R.; Diemert, D.; Spector, S.A.; Rouphael, N.; Creech, C.B.; et al. Efficacy and Safety of the mRNA-1273 SARS-CoV-2 Vaccine. N. Engl. J. Med. 2021, 384, 403-416. [CrossRef] [PubMed]

30. Tian, J.H.; Patel, N.; Haupt, R.; Zhou, H.; Weston, S.; Hammond, H.; Logue, J.; Portnoff, A.D.; Norton, J.; Guebre-Xabier, M.; et al. SARS-CoV-2 spike glycoprotein vaccine candidate NVX-CoV2373 immunogenicity in baboons and protection in mice. Nat. Commun. 2021, 12, 372. [CrossRef]

31. Grifoni, A.; Sidney, J.; Zhang, Y.; Scheuermann, R.H.; Peters, B.; Sette, A. A Sequence Homology and Bioinformatic Approach Can Predict Candidate Targets for Immune Responses to SARS-CoV-2. Cell Host Microbe 2020, 27, 671. [CrossRef] [PubMed]

32. Zhang, L.L.; Lin, D.Z.; Sun, X.Y.Y.; Curth, U.; Drosten, C.; Sauerhering, L.; Becker, S.; Rox, K.; Hilgenfeld, R. Crystal structure of SARS-CoV-2 main protease provides a basis for design of improved alpha-ketoamide inhibitors. Science 2020, 368, 409. [CrossRef] [PubMed]

33. Brewer, J.M. (How) do aluminium adjuvants work? Immunol. Lett. 2006, 102, 10-15. [CrossRef]

34. Kuroda, E.; Coban, C.; Ishii, K.J. Particulate Adjuvant and Innate Immunity: Past Achievements, Present Findings, and Future Prospects. Int. Rev. Immunol. 2013, 32, 209-220. [CrossRef]

35. Ellouz, F.; Adam, A.; Ciorbaru, R.; Lederer, E. Minimal structural requirements for adjuvant activity of bacterial peptidoglycan derivatives. Biochem. Biophys. Res. Commun. 1974, 59, 1317-1325. [CrossRef]

36. Chedid, L.; Parant, M.; Audibert, F.; Riveau, G.; Parant, F.; Lederer, E.; Choay, J.; Lefrancier, P. Biological activity of a new synthetic muramyl peptide adjuvant devoid of pyrogenicity. Infect. Immun. 1982, 35, 417-424. [CrossRef] [PubMed]

37. Aucouturier, J.; Dupuis, L.; Ganne, V. Adjuvants designed for veterinary and human vaccines. Vaccine 2001, 19, $2666-2672$. [CrossRef]

38. Negash, T.; Liman, M.; Rautenschlein, S. Mucosal application of cationic poly (D, L-lactide-co-glycolide) microparticles as carriers of DNA vaccine and adjuvants to protect chickens against infectious bursal disease. Vaccine 2013, 31, 3656-3662. [CrossRef]

39. Wen, Z.-S.; Xu, Y.-L.; Zou, X.-T.; Xu, Z.-R. Chitosan nanoparticles act as an adjuvant to promote both Th1 and Th2 immune responses induced by ovalbumin in mice. Mar. Drugs 2011, 9, 1038-1055. [CrossRef]

40. De Titta, A.; Ballester, M.; Julier, Z.; Nembrini, C.; Jeanbart, L.; Van Der Vlies, A.J.; Swartz, M.A.; Hubbell, J.A. Nanoparticle conjugation of CpG enhances adjuvancy for cellular immunity and memory recall at low dose. Proc. Natl. Acad. Sci. USA 2013, 110, 19902-19907. [CrossRef]

41. Hussain, M.J.; Wilkinson, A.; Bramwell, V.W.; Christensen, D.; Perrie, Y. T h1 immune responses can be modulated by varying dimethyldioctadecylammonium and distearoyl-sn-glycero-3-phosphocholine content in liposomal adjuvants. J. Pharmacy Pharmacol. 2014, 66, 358-366. [CrossRef] [PubMed]

42. Joshi, M.D.; Unger, W.J.; Storm, G.; Van Kooyk, Y.; Mastrobattista, E. Targeting tumor antigens to dendritic cells using particulate carriers. J. Controlled Release 2012, 161, 25-37. [CrossRef] [PubMed]

43. Petrovsky, N. Novel human polysaccharide adjuvants with dual Th1 and Th2 potentiating activity. Vaccine 2006, 24, S26-S29. [CrossRef]

44. Petrovsky, N.; Aguilar, J.C. Vaccine adjuvants: Current state and future trends. Immunol. Cell Biol. 2004, 82, 488-496. [CrossRef] 
45. Ghimire, T.R. The mechanisms of action of vaccines containing aluminum adjuvants: An in vitro vs in vivo paradigm. Springerplus 2015, 4, 1-18. [CrossRef]

46. Hogenesch, H. Mechanisms of stimulation of the immune response by aluminum adjuvants. Vaccine 2002, 20, S34-S39. [CrossRef]

47. Jones, L.S.; Peek, L.J.; Power, J.; Markham, A.; Yazzie, B.; Middaugh, C.R. Effects of adsorption to aluminum salt adjuvants on the structure and stability of model protein antigens. J. Biol. Chem. 2005, 280, 13406-13414. [CrossRef]

48. Deshmukh, S.S.; Magcalas, F.W.; Kalbfleisch, K.N.; Carpick, B.W.; Kirkitadze, M.D. Tuberculosis vaccine candidate: Characterization of H4-IC31 formulation and H4 antigen conformation. J. Pharm. Biomed. 2018, 157, 235-243. [CrossRef] [PubMed]

49. Doener, F.; Hong, H.S.; Meyer, I.; Tadjalli-Mehr, K.; Daehling, A.; Heidenreich, R.; Koch, S.D.; Fotin-Mleczek, M.; Gnad-Vogt, U. RNA-based adjuvant CV8102 enhances the immunogenicity of a licensed rabies vaccine in a first-in-human trial. Vaccine 2019, 37, 1819-1826. [CrossRef] [PubMed]

50. Ziegler, A.; Soldner, C.; Lienenklaus, S.; Spanier, J.; Trittel, S.; Riese, P.; Kramps, T.; Weiss, S.; Heidenreich, R.; Jasny, E. A new RNA-based adjuvant enhances virus-specific vaccine responses by locally triggering TLR-and RLH-dependent effects. J. Immunol. 2017, 198, 1595-1605. [CrossRef]

51. Heidenreich, R.; Jasny, E.; Kowalczyk, A.; Lutz, J.; Probst, J.; Baumhof, P.; Scheel, B.; Voss, S.; Kallen, K.J.; Fotin-Mleczek, M. A novel RNA-based adjuvant combines strong immunostimulatory capacities with a favorable safety profile. Int. J. Cancer 2015, 137, 372-384. [CrossRef]

52. Garçon, N.; Vaughn, D.W.; Didierlaurent, A.M. Development and evaluation of AS03, an Adjuvant System containing $\alpha-$ tocopherol and squalene in an oil-in-water emulsion. Expert Rev. Vaccines 2012, 11, 349-366. [CrossRef]

53. Morel, S.; Didierlaurent, A.; Bourguignon, P.; Delhaye, S.; Baras, B.; Jacob, V.; Planty, C.; Elouahabi, A.; Harvengt, P.; Carlsen, H. Adjuvant System AS03 containing $\alpha$-tocopherol modulates innate immune response and leads to improved adaptive immunity. Vaccine 2011, 29, 2461-2473. [CrossRef] [PubMed]

54. Cohet, C.; van der Most, R.; Bauchau, V.; Bekkat-Berkani, R.; Doherty, T.M.; Schuind, A.; Tavares Da Silva, F.; Rappuoli, R.; Garçon, N.; Innis, B.L. Safety of AS03-adjuvanted influenza vaccines: A review of the evidence. Vaccine 2019, 37, 3006-3021. [CrossRef] [PubMed]

55. Magnusson, S.E.; Reimer, J.M.; Karlsson, K.H.; Lilja, L.; Bengtsson, K.L.; Stertman, L. Immune enhancing properties of the novel Matrix-M $\mathrm{M}^{\mathrm{TM}}$ adjuvant leads to potentiated immune responses to an influenza vaccine in mice. Vaccine 2013, 31, 1725-1733. [CrossRef] [PubMed]

56. Reimer, J.M.; Karlsson, K.H.; Lövgren-Bengtsson, K.; Magnusson, S.E.; Fuentes, A.; Stertman, L. Matrix-M ${ }^{\mathrm{TM}}$ adjuvant induces local recruitment, activation and maturation of central immune cells in absence of antigen. PLoS ONE 2012, 7, e41451. [CrossRef] [PubMed]

57. Pedersen, G.; Major, D.; Roseby, S.; Wood, J.; Madhun, A.S.; Cox, R.J. Matrix-M adjuvanted virosomal H5N1 vaccine confers protection against lethal viral challenge in a murine model. Influenza Other Respir. Viruses 2011, 5, 426-437. [CrossRef]

58. Madhun, A.S.; Haaheim, L.R.; Nilsen, M.V.; Cox, R.J. Intramuscular Matrix-M-adjuvanted virosomal H5N1 vaccine induces high frequencies of multifunctional Th1 CD4+ cells and strong antibody responses in mice. Vaccine 2009, 27, 7367-7376. [CrossRef]

59. Radošević, K.; Rodriguez, A.; Mintardjo, R.; Tax, D.; Bengtsson, K.L.; Thompson, C.; Zambon, M.; Weverling, G.J.; UytdeHaag, F.; Goudsmit, J. Antibody and T-cell responses to a virosomal adjuvanted H9N2 avian influenza vaccine: Impact of distinct additional adjuvants. Vaccine 2008, 26, 3640-3646. [CrossRef] [PubMed]

60. Cox, F.; Roos, A.; Hafkemeijer, N.; Baart, M.; Tolboom, J.; Dekking, L.; Stittelaar, K.; Goudsmit, J.; Radošević, K.; Saeland, E. Matrix-M adjuvated seasonal virosomal influenza vaccine induces partial protection in mice and ferrets against avian $\mathrm{H} 5$ and $\mathrm{H} 7$ challenge. PLoS ONE 2015, 10, e0135723. [CrossRef]

61. Fischer, R.; Buyel, J.F. Molecular farming-The slope of enlightenment. Biotechnol. Adv. 2020, 40, 107519. [CrossRef]

62. Hiatt, A.; Cafferkey, R.; Bowdish, K. Production of antibodies in transgenic plants. Nature 1989, 342, 76-78. [CrossRef]

63. Ma, J.K.; Drake, P.M.; Christou, P. The production of recombinant pharmaceutical proteins in plants. Nat. Rev. Genet. 2003, 4, 794-805. [CrossRef]

64. Stoger, E.; Fischer, R.; Moloney, M.; Ma, J.K. Plant molecular pharming for the treatment of chronic and infectious diseases. Annu. Rev. Plant. Biol. 2014, 65, 743-768. [CrossRef]

65. Tschofen, M.; Knopp, D.; Hood, E.; Stoger, E. Plant Molecular Farming: Much More than Medicines. Annu. Rev. Anal. Chem. (Palo Alto Calif.) 2016, 9, 271-294. [CrossRef] [PubMed]

66. Rosales-Mendoza, S.; Marquez-Escobar, V.A.; Gonzalez-Ortega, O.; Nieto-Gomez, R.; Arevalo-Villalobos, J.I. What Does PlantBased Vaccine Technology Offer to the Fight against COVID-19? Vaccines 2020, 8, 183. [CrossRef]

67. Sijmons, P.C.; Dekker, B.M.; Schrammeijer, B.; Verwoerd, T.C.; van den Elzen, P.J.; Hoekema, A. Production of correctly processed human serum albumin in transgenic plants. Biotechnology 1990, 8, 217-221. [CrossRef]

68. Twyman, R.M.; Stoger, E.; Schillberg, S.; Christou, P.; Fischer, R. Molecular farming in plants: Host systems and expression technology. Trends Biotechnol. 2003, 21, 570-578. [CrossRef] [PubMed]

69. Salazar-Gonzalez, J.A.; Banuelos-Hernandez, B.; Rosales-Mendoza, S. Current status of viral expression systems in plants and perspectives for oral vaccines development. Plant. Mol. Biol. 2015, 87, 203-217. [CrossRef] [PubMed]

70. García-Hernández, A.L.; Rubio-Infante, N.; Moreno-Fierros, L. Mucosal Immunology and Oral Vaccination. In Genetically Engineered Plants as a Source of Vaccines Against Wide Spread Diseases: An Integrated View; Rosales-Mendoza, S., Ed.; Springer: New York, NY, USA, 2014; pp. 15-42. 
71. Rech, E.L.; Vianna, G.R.; Aragao, F.J. High-efficiency transformation by biolistics of soybean, common bean and cotton transgenic plants. Nat. Protoc. 2008, 3, 410-418. [CrossRef]

72. Rech, E.L. Seeds, recombinant DNA and biodiversity. Seed Sci. Res. 2012, 22, S36-S44. [CrossRef]

73. Pogrebnyak, N.; Golovkin, M.; Andrianov, V.; Spitsin, S.; Smirnov, Y.; Egolf, R.; Koprowski, H. Severe acute respiratory syndrome (SARS) S protein production in plants: Development of recombinant vaccine. Proc. Natl. Acad. Sci. USA 2005, 102, 9062-9067. [CrossRef]

74. Li, H.Y.; Ramalingam, S.; Chye, M.L. Accumulation of recombinant SARS-CoV spike protein in plant cytosol and chloroplasts indicate potential for development of plant-derived oral vaccines. Exp. Biol. Med. 2006, 231, 1346-1352. [CrossRef] [PubMed]

75. Zheng, N.Y.; Xia, R.; Yang, C.P.; Yin, B.J.; Li, Y.; Duan, C.G.; Liang, L.M.; Guo, H.S.; Xie, Q. Boosted expression of the SARS-CoV nucleocapsid protein in tobacco and its immunogenicity in mice. Vaccine 2009, 27, 5001-5007. [CrossRef] [PubMed]

76. Demurtas, O.C.; Massa, S.; Illiano, E.; De Martinis, D.; Chan, P.K.S.; Di Bonito, P.; Franconi, R. Antigen Production in Plant to Tackle Infectious Diseases Flare Up: The Case of SARS. Front. Plant Sci 2016, 7, 54. [CrossRef]

77. Daniell, H.; Chan, H.T.; Pasoreck, E.K. Vaccination via Chloroplast Genetics: Affordable Protein Drugs for the Prevention and Treatment of Inherited or Infectious Human Diseases. Annu. Rev. Genet. 2016, 50, 595-618. [CrossRef]

78. Bilichak, A.; Gaudet, D.; Laurie, J. Emerging Genome Engineering Tools in Crop Research and Breeding. Methods Mol. Biol. 2020, 2072, 165-181. [CrossRef]

79. Olejniczak, S.A.; Lojewska, E.; Kowalczyk, T.; Sakowicz, T. Chloroplasts: State of research and practical applications of plastome sequencing. Planta 2016, 244, 517-527. [CrossRef]

80. Arai, Y.; Shikanai, T.; Doi, Y.; Yoshida, S.; Yamaguchi, I.; Nakashita, H. Production of polyhydroxybutyrate by polycistronic expression of bacterial genes in tobacco plastid. Plant. Cell Physiol. 2004, 45, 1176-1184. [CrossRef]

81. Salazar-González, J.A.; Monreal-Escalante, E.; Díaz, A.H.; Koop, H.U.; Rosales-Mendoza, S. Plastid-Based Expression Strategies In Genetically Engineered Plants as a Source of Vaccines Against Wide Spread Diseases: An Integrated View; Rosales-Mendoza, S., Ed.; Springer: New York, NY, USA, 2014; pp. 61-78.

82. Marillonnet, S.; Giritch, A.; Gils, M.; Kandzia, R.; Klimyuk, V.; Gleba, Y. In planta engineering of viral RNA replicons: Efficient assembly by recombination of DNA modules delivered by Agrobacterium (vol 18, pg 3852, 2004). Proc. Natl. Acad. Sci. USA 2004, 101, 15546. [CrossRef]

83. Peyret, H.; Lomonossoff, G.P. When plant virology met Agrobacterium: The rise of the deconstructed clones. Plant. Biotechnol. J. 2015, 13, 1121-1135. [CrossRef]

84. Marquez-Escobar, V.A.; Rosales-Mendoza, S.; Beltran-Lopez, J.I.; Gonzalez-Ortega, O. Plant-based vaccines against respiratory diseases: Current status and future prospects. Expert Rev. Vaccines 2017, 16, 137-149. [CrossRef]

85. Gomez, E.; Lucero, M.S.; Zoth, S.C.; Carballeda, J.M.; Gravisaco, M.J.; Berinstein, A. Transient expression of VP2 in Nicotiana benthamiana and its use as a plant-based vaccine against Infectious Bursal Disease Virus. Vaccine 2013, 31, 2623-2627. [CrossRef] [PubMed]

86. Musiychuk, K.; Stephenson, N.; Bi, H.; Farrance, C.E.; Orozovic, G.; Brodelius, M.; Brodelius, P.; Horsey, A.; Ugulava, N.; Shamloul, A.M.; et al. A launch vector for the production of vaccine antigens in plants. Influenza Other Respir. Viruses 2007, 1, 19-25. [CrossRef] [PubMed]

87. Rybicki, E.P. Plant-based vaccines against viruses. Virol. J. 2014, 11, 205. [CrossRef] [PubMed]

88. D'Aoust, M.A.; Lavoie, P.O.; Couture, M.M.J.; Trepanier, S.; Guay, J.M.; Dargis, M.; Mongrand, S.; Landry, N.; Ward, B.J.; Vezina, L.P. Influenza virus-like particles produced by transient expression in Nicotiana benthamiana induce a protective immune response against a lethal viral challenge in mice. Plant. Biotechnol. J. 2008, 6, 930-940. [CrossRef] [PubMed]

89. Landry, N.; Ward, B.J.; Trepanier, S.; Montomoli, E.; Dargis, M.; Lapini, G.; Vezina, L.P. Preclinical and clinical development of plant-made virus-like particle vaccine against avian H5N1 influenza. PLoS ONE 2010, 5, e15559. [CrossRef]

90. Le Mauff, F.; Mercier, G.; Chan, P.; Burel, C.; Vaudry, D.; Bardor, M.; Vezina, L.P.; Couture, M.; Lerouge, P.; Landry, N. Biochemical composition of haemagglutinin-based influenza virus-like particle vaccine produced by transient expression in tobacco plants. Plant Biotechnol. J. 2015, 13, 717-725. [CrossRef]

91. Shoji, Y.; Prokhnevsky, A.; Leffet, B.; Vetter, N.; Tottey, S.; Satinover, S.; Musiychuk, K.; Shamloul, M.; Norikane, J.; Jones, R.M.; et al. Immunogenicity of H1N1 influenza virus-like particles produced in Nicotiana benthamiana. Hum. Vaccin Immunother. 2015, 11, 118-123. [CrossRef]

92. Shoji, Y.; Farrance, C.E.; Bautista, J.; Bi, H.; Musiychuk, K.; Horsey, A.; Park, H.; Jaje, J.; Green, B.J.; Shamloul, M.; et al. A plant-based system for rapid production of influenza vaccine antigens. Influenza Other Respir. Viruses 2012, 6, 204-210. [CrossRef]

93. Shoji, Y.; Chichester, J.A.; Jones, M.; Manceva, S.D.; Damon, E.; Mett, V.; Musiychuk, K.; Bi, H.; Farrance, C.; Shamloul, M.; et al. Plant-based rapid production of recombinant subunit hemagglutinin vaccines targeting H1N1 and H5N1 influenza. Hum. Vaccines 2011, 7, 41-50. [CrossRef]

94. Cummings, J.F.; Guerrero, M.L.; Moon, J.E.; Waterman, P.; Nielsen, R.K.; Jefferson, S.; Gross, F.L.; Hancock, K.; Katz, J.M.; Yusibov, V.; et al. Safety and immunogenicity of a plant-produced recombinant monomer hemagglutinin-based influenza vaccine derived from influenza A (H1N1)pdm09 virus: A Phase 1 dose-escalation study in healthy adults. Vaccine 2014, 32, 2251-2259. [CrossRef] 
95. Neuhaus, V.; Chichester, J.A.; Ebensen, T.; Schwarz, K.; Hartman, C.E.; Shoji, Y.; Guzman, C.A.; Yusibov, V.; Sewald, K.; Braun, A. A new adjuvanted nanoparticle-based H1N1 influenza vaccine induced antigen-specific local mucosal and systemic immune responses after administration into the lung. Vaccine 2014, 32, 3216-3222. [CrossRef] [PubMed]

96. Meng, J.; Stobart, C.C.; Hotard, A.L.; Moore, M.L. An overview of respiratory syncytial virus. PLoS Pathog. 2014, 10 , e1004016. [CrossRef] [PubMed]

97. Shi, T.; McAllister, D.A.; O’Brien, K.L.; Simoes, E.A.F.; Madhi, S.A.; Gessner, B.D.; Polack, F.P.; Balsells, E.; Acacio, S.; Aguayo, C.; et al. Global, regional, and national disease burden estimates of acute lower respiratory infections due to respiratory syncytial virus in young children in 2015: A systematic review and modelling study. Lancet 2017, 390, 946-958. [CrossRef]

98. Ackerson, B.; Tseng, H.F.; Sy, L.S.; Solano, Z.; Slezak, J.; Luo, Y.; Fischetti, C.A.; Shinde, V. Severe Morbidity and Mortality Associated With Respiratory Syncytial Virus Versus Influenza Infection in Hospitalized Older Adults. Clin. Infect. Dis. 2019, 69, 197-203. [CrossRef]

99. Foley, D.A.; Phuong, L.K.; Englund, J.A. Respiratory syncytial virus immunisation overview. J. Paediatr. Child Health 2020, 56, 1865-1867. [CrossRef]

100. Sandhu, J.S.; Krasnyanski, S.F.; Domier, L.L.; Korban, S.S.; Osadjan, M.D.; Buetow, D.E. Oral immunization of mice with transgenic tomato fruit expressing respiratory syncytial virus-F protein induces a systemic immune response. Transgenic Res. 2000, 9, 127-135. [CrossRef] [PubMed]

101. Gilbert, C.; Robinson, K.; Le Page, R.W.F.; Wells, J.M. Heterologous expression of an immunogenic pneumococcal type 3 capsular polysaccharide in Lactococcus lactis. Infect. Immun. 2000, 68, 3251-3260. [CrossRef]

102. van Deuren, M.; Brandtzaeg, P.; van der Meer, J.W.M. Update on meningococcal disease with emphasis on pathogenesis and clinical management. Clin. Microbiol Rev. 2000, 13, 144. [CrossRef]

103. Smith, C.M.; Fry, S.C.; Gough, K.C.; Patel, A.J.F.; Glenn, S.; Goldrick, M.; Roberts, I.S.; Whitelam, G.C.; Andrew, P.W. Recombinant Plants Provide a New Approach to the Production of Bacterial Polysaccharide for Vaccines. PLoS ONE 2014, 9, e88144. [CrossRef] [PubMed]

104. Abrami, L.; Reig, N.; van der Goot, F.G. Anthrax toxin: The long and winding road that leads to the kill. Trends Microbiol. 2005, 13, 72-78. [CrossRef] [PubMed]

105. Guichard, A.; Nizet, V.; Bier, E. New insights into the biological effects of anthrax toxins: Linking cellular to organismal responses. Microbes Infect. 2012, 14, 97-118. [CrossRef]

106. Aloni-Grinstein, R.; Gat, O.; Altboum, Z.; Velan, B.; Cohen, S.; Shafferman, A. Oral spore vaccine based on live attenuated nontoxinogenic Bacillus anthracis expressing recombinant mutant protective antigen. Infect. Immun. 2005, 73, 4043-4053. [CrossRef]

107. Baillie, L.W.J.; Rodriguez, A.L.; Moore, S.; Atkins, H.S.; Feng, C.; Nataro, J.R.; Pasetti, M.F. Towards a human oral vaccine for anthrax: The utility of a Salmonella Typhi Ty21a-based prime-boost immunization strategy. Vaccine 2008, 26, 6083-6091. [CrossRef] [PubMed]

108. Bielinska, A.U.; Janczak, K.W.; Landers, J.J.; Makidon, P.; Sower, L.E.; Peterson, J.W.; Baker, J.R., Jr. Mucosal immunization with a novel nanoemulsion-based recombinant anthrax protective antigen vaccine protects against Bacillus anthracis spore challenge. Infect. Immun. 2007, 75, 4020-4029. [CrossRef] [PubMed]

109. Brey, R.N. Molecular basis for improved anthrax vaccines. Adv. Drug Deliv. Rev. 2005, 57, 1266-1292. [CrossRef]

110. Twyman, R.M.; Schillberg, S.; Fischer, R. Transgenic plants in the biopharmaceutical market. Expert Opin. Emerg. Drugs 2005, 10, 185-218. [CrossRef]

111. Walmsley, A.M.; Arntzen, C.J. Plant cell factories and mucosal vaccines. Curr. Opin. Biotechnol. 2003, 14, 145-150. [CrossRef]

112. Aziz, M.A.; Singh, S.; Anand Kumar, P.; Bhatnagar, R. Expression of protective antigen in transgenic plants: A step towards edible vaccine against anthrax. Biochem. Biophys. Res. Commun. 2002, 299, 345-351. [CrossRef]

113. Aziz, M.A.; Sikriwal, D.; Singh, S.; Jarugula, S.; Kumar, P.A.; Bhatnagar, R. Transformation of an edible crop with the pagA gene of Bacillus anthracis. FASEB J. 2005, 19, 1501-1503. [CrossRef] [PubMed]

114. Gorantala, J.; Grover, S.; Rahi, A.; Chaudhary, P.; Rajwanshi, R.; Sarin, N.B.; Bhatnagar, R. Generation of protective immune response against anthrax by oral immunization with protective antigen plant-based vaccine. J. Biotechnol. 2014, 176, 1-10. [CrossRef] [PubMed]

115. Chichester, J.A.; Manceva, S.D.; Rhee, A.; Coffin, M.V.; Musiychuk, K.; Mett, V.; Shamloul, M.; Norikane, J.; Streatfield, S.J.; Yusibov, V. A plant-produced protective antigen vaccine confers protection in rabbits against a lethal aerosolized challenge with Bacillus anthracis Ames spores. Hum. Vaccin Immunother. 2013, 9, 544-552. [CrossRef]

116. Bandurska, K.; Brodzik, R.; Spitsin, S.; Kohl, T.; Portocarrero, C.; Smirnov, Y.; Pogrebnyak, N.; Sirko, A.; Koprowski, H.; Golovkin, M. Plant-produced hepatitis B core protein chimera carrying anthrax protective antigen domain-4. Hybridoma (Larchmt) 2008, 27, 241-247. [CrossRef]

117. Zenteno-Cuevas, R. Successes and failures in human tuberculosis vaccine development. Expert Opin. Biol. Ther. 2017, 17, 1481-1491. [CrossRef] [PubMed]

118. Zhang, Y.; Chen, S.; Li, J.; Liu, Y.; Hu, Y.; Cai, H. Oral immunogenicity of potato-derived antigens to Mycobacterium tuberculosis in mice. Acta Biochim. Biophys. Sin. (Shanghai) 2012, 44, 823-830. [CrossRef] [PubMed] 
119. Pepponi, I.; Diogo, G.R.; Stylianou, E.; van Dolleweerd, C.J.; Drake, P.M.W.; Paul, M.J.; Sibley, L.; Ma, J.K.C.; Reljic, R. Plantderived recombinant immune complexes as self-adjuvanting TB immunogens for mucosal boosting of BCG. Plant. Biotechnol. J. 2014, 12, 840-850. [CrossRef] [PubMed]

120. Rigano, M.M.; Dreitz, S.; Kipnis, A.P.; Izzo, A.A.; Walmsley, A.M. Oral immunogenicity of a plant-made, subunit, tuberculosis vaccine. Vaccine 2006, 24, 691-695. [CrossRef] [PubMed]

121. Rigano, M.M.; Alvarez, M.L.; Pinkhasov, J.; Jin, Y.; Sala, F.; Arntzen, C.J.; Walmsley, A.M. Production of a fusion protein consisting of the enterotoxigenic Escherichia coli heat-labile toxin B subunit and a tuberculosis antigen in Arabidopsis thaliana. Plant. Cell Rep. 2004, 22, 502-508. [CrossRef]

122. Uvarova, E.A.; Belavin, P.A.; Permyakova, N.V.; Zagorskaya, A.A.; Nosareva, O.V.; Kakimzhanova, A.A.; Deineko, E.V. Oral Immunogenicity of Plant-Made Mycobacterium tuberculosis ESAT6 and CFP10. Biomed. Res. Int. 2013, 2013, 1-8. [CrossRef]

123. Lakshmi, P.S.; Verma, D.; Yang, X.D.; Lloyd, B.; Daniell, H. Low Cost Tuberculosis Vaccine Antigens in Capsules: Expression in Chloroplasts, Bio-Encapsulation, Stability and Functional Evaluation In Vitro. PLoS ONE 2013, 8, e54708. [CrossRef]

124. Smart, V.; Foster, P.S.; Rothenberg, M.E.; Higgins, T.J.V.; Hogan, S.P. A plant-based allergy vaccine suppresses experimental asthma via an IFN-gamma and CD4(+) CD45RB(low) T cell-dependent mechanism. J. Immunol. 2003, 171, 2116-2126. [CrossRef]

125. Suzuki, K.; Kaminuma, O.; Yang, L.J.; Takai, T.; Mori, A.; Umezu-Goto, M.; Ohtomo, T.; Ohmachi, Y.; Noda, Y.; Hirose, S.; et al. Prevention of allergic asthma by vaccination with transgenic rice seed expressing mite allergen: Induction of allergen-specific oral tolerance without bystander suppression. Plant. Biotechnol. J. 2011, 9, 982-990. [CrossRef]

126. Bateman, E.D.; Hurd, S.S.; Barnes, P.J.; Bousquet, J.; Drazen, J.M.; FitzGerald, J.M.; Gibson, P.; Ohta, K.; O’Byrne, P.; Pedersen, S.E.; et al. Global strategy for asthma management and prevention: GINA executive summary (vol 31, pg 143, 2008). Eur. Respir. J. 2018, 51, 143-178. [CrossRef]

127. Li, C.; Jiang, Y.; Guo, W.; Liu, Z. Production of a chimeric allergen derived from the major allergen group 1 of house dust mite species in Nicotiana benthamiana. Hum. Immunol. 2013, 74, 531-537. [CrossRef]

128. Rosales-Mendoza, S.; Salazar-Gonzalez, J.A. Immunological aspects of using plant cells as delivery vehicles for oral vaccines. Expert Rev. Vaccines 2014, 13, 737-749. [CrossRef]

129. Lee, M.F.; Chiang, C.H.; Li, Y.L.; Wang, N.M.; Song, P.P.; Lin, S.J.; Chen, Y.H. Oral edible plant vaccine containing hypoallergen of American cockroach major allergen Per a 2 prevents roach-allergic asthma in a murine model. PLoS ONE 2018, 13 , e0201281. [CrossRef] [PubMed]

130. Perotti, M.; Perez, L. Virus-Like Particles and Nanoparticles for Vaccine Development against HCMV. Viruses 2019, 12, 35. [CrossRef]

131. Bachmann, M.F.; Jennings, G.T. Vaccine delivery: A matter of size, geometry, kinetics and molecular patterns. Nat. Rev. Immunol. 2010, 10, 787-796. [CrossRef] [PubMed]

132. Chabeda, A.; van Zyl, A.R.; Rybicki, E.P.; Hitzeroth, I.I. Substitution of Human Papillomavirus Type 16 L2 Neutralizing Epitopes Into L1 Surface Loops: The Effect on Virus-Like Particle Assembly and Immunogenicity. Front. Plant. Sci. 2019, 10, 779. [CrossRef]

133. Lopez-Sagaseta, J.; Malito, E.; Rappuoli, R.; Bottomley, M.J. Self-assembling protein nanoparticles in the design of vaccines. Comput. Struct. Biotechnol. J. 2016, 14, 58-68. [CrossRef]

134. Manolova, V.; Flace, A.; Bauer, M.; Schwarz, K.; Saudan, P.; Bachmann, M.F. Nanoparticles target distinct dendritic cell populations according to their size. Eur. J. Immunol. 2008, 38, 1404-1413. [CrossRef] [PubMed]

135. Ward, B.J.; Gobeil, P.; Séguin, A.; Atkins, J.; Boulay, I.; Charbonneau, P.-Y.; Couture, M.; D'Aoust, M.-A.; Dhaliwall, J.; Finkle, C.; et al. Phase 1 trial of a Candidate Recombinant Virus-Like Particle Vaccine for Covid-19 Disease Produced in Plants. medRxiv 2020. [CrossRef]

136. Shin, M.D.; Shukla, S.; Chung, Y.H.; Beiss, V.; Chan, S.K.; Ortega-Rivera, O.A.; Wirth, D.M.; Chen, A.; Sack, M.; Pokorski, J.K.; et al. COVID-19 vaccine development and a potential nanomaterial path forward. Nat. Nanotechnol. 2020, 15, 646-655. [CrossRef] [PubMed]

137. Medhi, R.; Srinoi, P.; Ngo, N.; Tran, H.V.; Lee, T.R. Nanoparticle-Based Strategies to Combat COVID-19. ACS Appl. Nano Mater. 2020, 3, 8557-8580. [CrossRef]

138. Rao, L.; Xia, S.; Xu, W.; Tian, R.; Yu, G.; Gu, C.; Pan, P.; Meng, Q.F.; Cai, X.; Qu, D.; et al. Decoy nanoparticles protect against COVID-19 by concurrently adsorbing viruses and inflammatory cytokines. Proc. Natl. Acad. Sci. USA 2020, 117, 27141-27147. [CrossRef] [PubMed]

139. Campos, E.V.R.; Pereira, A.E.S.; de Oliveira, J.L.; Carvalho, L.B.; Guilger-Casagrande, M.; de Lima, R.; Fraceto, L.F. How can nanotechnology help to combat COVID-19? Opportunities and urgent need. J. Nanobiotechnol. 2020, 18, 1-23. [CrossRef]

140. Ruiz-Hitzky, E.; Darder, M.; Wicklein, B.; Ruiz-Garcia, C.; Martin-Sampedro, R.; del Real, G.; Aranda, P. Nanotechnology Responses to COVID-19. Adv. Healthc. Mater. 2020, 9, 2000979. [CrossRef]

141. Gurunathan, S.; Qasim, M.; Choi, Y.; Do, J.T.; Park, C.; Hong, K.; Kim, J.H.; Song, H. Antiviral Potential of Nanoparticles-Can Nanoparticles Fight Against Coronaviruses? Nanomaterials 2020, 10, 1645. [CrossRef]

142. Mamedov, T.; Yuksel, D.; Ilgın, M.; Gürbüzaslan, İ.; Gulec, B.; Mammadova, G.; Say, D.; Hasanova, G. Engineering, production and characterization of Spike and Nucleocapsid structural proteins of SARS-CoV-2 in Nicotiana benthamiana as vaccine candidates against COVID-19. bioRxiv 2020. [CrossRef]

143. Medicago. COVID-19 Vaccine and Antibody Development Program. Available online: https://www.medicago.com/en/covid19-programs / (accessed on 28 May 2021). 
144. BAT. BAT Makes Progress on COVID-19 Vaccine \& Provides Community Support. Available online: https://www.bat.com/ group/sites/UK_9D9KCY.nsf/vwPagesWebLive/DOBPMBZC (accessed on 14 June 2021).

145. iBio. iBio Announces Development of Proprietary COVID-19 Vaccine Candidates. Available online: https://www.ibioinc.com/ therapeutics-and-vaccines\#covid-19-overview (accessed on 14 June 2021).

146. Roose, K.; De Baets, S.; Schepens, B.; Saelens, X. Hepatitis B core-based virus-like particles to present heterologous epitopes. Expert Rev. Vaccines 2013, 12, 183-198. [CrossRef]

147. Moradi Vahdat, M.; Hemmati, F.; Ghorbani, A.; Rutkowska, D.; Afsharifar, A.; Eskandari, M.H.; Rezaei, N.; Niazi, A. Hepatitis B core-based virus-like particles: A platform for vaccine development in plants. Biotechnol. Rep. 2021, 29, e00605. [CrossRef]

148. Zahmanova, G.; Mazalovska, M.; Takova, K.; Toneva, V.; Minkov, I.; Peyret, H.; Lomonossoff, G. Efficient Production of Chimeric Hepatitis B Virus-Like Particles Bearing an Epitope of Hepatitis E Virus Capsid by Transient Expression in Nicotiana benthamiana. Life 2021, 11, 64. [CrossRef]

149. Arntzen, C. Plant-made pharmaceuticals: From ‘Edible Vaccines' to Ebola therapeutics. Plant. Biotechnol. J. 2015, 13, 1013. [CrossRef] [PubMed]

150. Chansaenroj, J.; Chuchaona, W.; Thanusuwannasak, T.; Duang-In, A.; Puenpa, J.; Vutithanachot, V.; Vongpunsawad, S.; Poovorawan, Y. Prevalence of poliovirus vaccine strains in randomized stool samples from 2010 to 2018: Encompassing transition from the trivalent to bivalent oral poliovirus vaccine. Virusdisease 2019, 30, 201-206. [CrossRef] [PubMed]

151. Spice, A.J.; Aw, R.; Bracewell, D.G.; Polizzi, K.M. Synthesis and Assembly of Hepatitis B Virus-Like Particles in a Pichia pastoris Cell-Free System. Front. Bioeng. Biotechnol. 2020, 8, 72. [CrossRef]

152. D'Aoust, M.A.; Couture, M.M.; Charland, N.; Trepanier, S.; Landry, N.; Ors, F.; Vezina, L.P. The production of hemagglutininbased virus-like particles in plants: A rapid, efficient and safe response to pandemic influenza. Plant. Biotechnol. J. 2010, 8, 607-619. [CrossRef] [PubMed]

153. Hodgins, B.; Pillet, S.; Landry, N.; Ward, B.J. A plant-derived VLP influenza vaccine elicits a balanced immune response even in very old mice with co-morbidities. PLoS ONE 2019, 14, e0210009. [CrossRef]

154. Herbst-Kralovetz, M.; Mason, H.S.; Chen, Q. Norwalk virus-like particles as vaccines. Expert Rev. Vaccines 2010, 9, $299-307$. [CrossRef] [PubMed]

155. Mbewana, S.; Meyers, A.E.; Rybicki, E.P. Chimaeric Rift Valley Fever Virus-Like Particle Vaccine Candidate Production in Nicotiana benthamiana. Biotechnol. J. 2019, 14, 1800238. [CrossRef]

156. Meyers, A.; Chakauya, E.; Shephard, E.; Tanzer, F.L.; Maclean, J.; Lynch, A.; Williamson, A.L.; Rybicki, E.P. Expression of HIV-1 antigens in plants as potential subunit vaccines. BMC Biotechnol. 2008, 8, 53. [CrossRef] [PubMed]

157. Deml, L.; Speth, C.; Dierich, M.P.; Wolf, H.; Wagner, R. Recombinant HIV-1 Pr55gag virus-like particles: Potent stimulators of innate and acquired immune responses. Mol. Immunol. 2005, 42, 259-277. [CrossRef]

158. Ruiz, V.; Baztarrica, J.; Rybicki, E.P.; Meyers, A.E.; Wigdorovitz, A. Minimally processed crude leaf extracts of Nicotiana benthamiana containing recombinant foot and mouth disease virus-like particles are immunogenic in mice. Biotechnol. Rep. (Amst.) 2018, 20, e00283. [CrossRef]

159. Ho, Y.; Lin, P.H.; Liu, C.Y.Y.; Lee, S.P.; Chao, Y.C. Assembly of human severe acute respiratory syndrome coronavirus-like particles. Biochem. Biophys. Res. Commun. 2004, 318, 833-838. [CrossRef]

160. Bai, B.K.; Hu, Q.X.; Hu, H.; Zhou, P.; Shi, Z.L.; Meng, J.; Lu, B.J.; Huang, Y.; Mao, P.Y.; Wang, H. Virus-Like Particles of SARS-Like Coronavirus Formed by Membrane Proteins from Different Origins Demonstrate Stimulating Activity in Human Dendritic Cells. PLoS ONE 2008, 3, e2685. [CrossRef] [PubMed]

161. Lu, B.J.; Huang, Y.; Huang, L.; Li, B.; Zheng, Z.H.; Chen, Z.; Chen, J.J.; Hu, Q.X.; Wang, H.Z. Effect of mucosal and systemic immunization with virus-like particles of severe acute respiratory syndrome coronavirus in mice. Immunology 2010, 130, 254-261. [CrossRef] [PubMed]

162. Satija, N.; Lal, S.K. The molecular biology of SARS coronavirus. Ann. N. Y. Acad. Sci. 2007, 1102, 26-38. [CrossRef]

163. Balke, I.; Zeltins, A. Recent Advances in the Use of Plant Virus-Like Particles as Vaccines. Viruses 2020, 12, 270. [CrossRef]

164. Kirk, D.D.; McIntosh, K.; Walmsley, A.M.; Peterson, R.K.D. Risk analysis for plant-made vaccines. Transgenic Res. 2005, 14, 449-462. [CrossRef] [PubMed]

165. Goodman, R.E.; Vieths, S.; Sampson, H.A.; Hill, D.; Ebisawa, M.; Taylor, S.L.; van Ree, R. Allergenicity assessment of genetically modified crops-what makes sense? (vol 26, pg 73, 2008). Nat. Biotechnol. 2008, 26, 241. [CrossRef]

166. van Ree, R. Carbohydrate epitopes and their relevance for the diagnosis and treatment of allergic diseases. Int. Arch. Allergy Immunol. 2002, 129, 189-197. [CrossRef] [PubMed]

167. Kirk, D.D.; Webb, S.R. The next 15 years: Taking plant-made vaccines beyond proof of concept. Immunol. Cell Biol. 2005, 83, 248-256. [CrossRef]

168. Azegami, T.; Itoh, H.; Kiyono, H.; Yuki, Y. Novel transgenic rice-based vaccines. Arch. Immunol. Ther. Exp. (Warsz.) 2015, 63, 87-99. [CrossRef] [PubMed] 